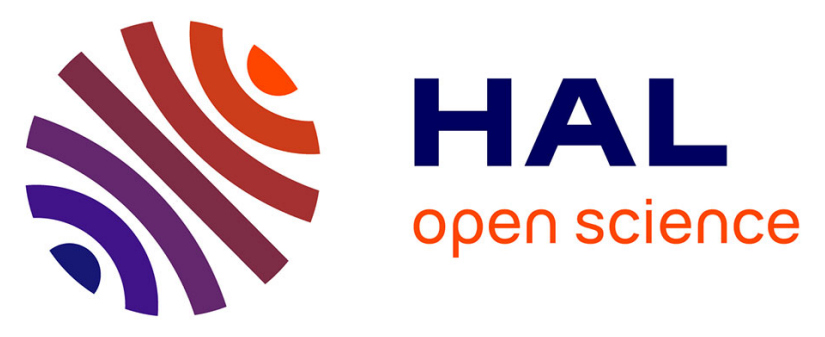

\title{
Dendrimeric Nanoparticles for Two-Photon Photodynamic Therapy and Imaging Synthesis, Photophysical Properties, Innocuousness in Daylight and Cytotoxicity under Two-Photon Irradiation in the NIR
}

\author{
A. Sourdon, M. Gary-Bobo, M. Maynadier, M. Garcia, Jean Pierre Majoral,
} A.-M. Caminade, O. Mongin, Mireille Blanchard-desce

\section{To cite this version:}

A. Sourdon, M. Gary-Bobo, M. Maynadier, M. Garcia, Jean Pierre Majoral, et al.. Dendrimeric Nanoparticles for Two-Photon Photodynamic Therapy and Imaging Synthesis, Photophysical Properties, Innocuousness in Daylight and Cytotoxicity under Two-Photon Irradiation in the NIR. Chemistry - A European Journal, 2019, 25 (14), pp.3637-3649. 10.1002/chem.201805617 . hal-02051161

HAL Id: hal-02051161

https://hal-univ-rennes1.archives-ouvertes.fr/hal-02051161

Submitted on 5 Mar 2019

HAL is a multi-disciplinary open access archive for the deposit and dissemination of scientific research documents, whether they are published or not. The documents may come from teaching and research institutions in France or abroad, or from public or private research centers.
L'archive ouverte pluridisciplinaire HAL, est destinée au dépôt et à la diffusion de documents scientifiques de niveau recherche, publiés ou non, émanant des établissements d'enseignement et de recherche français ou étrangers, des laboratoires publics ou privés. 


\title{
Dendrimeric nanoparticles for two-photon photodynamic therapy and imaging: synthesis, photophysical properties, innocuousness in daylight and cytotoxicity under two-photon irradiation in the NIR
}

\author{
Aude Sourdon, ${ }^{[a]}$ Magali Gary-Bobo, ${ }^{[c]}$ Marie Maynadier, ${ }^{[c]}$ Marcel Garcia, ${ }^{[c]}$ Jean-Pierre Majoral, ${ }^{[d, e]}$ \\ Anne-Marie Caminade, ${ }^{[\mathrm{d}, \mathrm{e}]}$ Olivier Mongin ${ }^{*[a]}$ and Mireille Blanchard-Desce ${ }^{*[\mathrm{~b}]}$
}

\begin{abstract}
The synthesis and the photophysical properties of a new class of fully organic monodisperse nanoparticles for combined twophoton imaging and photodynamic therapy are described. The design of such nanoparticle is based on the covalent immobilization of a dedicated quadrupolar dye - which combine large two-photon absorbing (2PA) properties, fluorescence and singlet oxygen generation ability - in a phosphorous-based dendrimeric architecture. Firstly, a bifunctional quadrupolar dye bearing two different grafting moieties, a phenol function and an aldehyde function, was synthesized. It was then covalently grafted through its phenol function to a phosphorus-based dendrimer scaffold of generation 1. The remaining aldehyde functions were then used to carry on the dendrimer synthesis up to generation 2 introducing finally at its periphery 24 water-solubilizing triethyleneglycol chains. A dendrimer confining 12 photoactive quadrupolar units in its inner scaffold and showing water solubility was thus obtained. Interestingly, the G1 and G2 dendrimers retain some fluorescence as well as significant singlet oxygen production efficiencies while they were found to show very high 2PA cross-sections in a broad range of the NIR biological spectral window. Hydrophilic dendrimer $\mathrm{G} 2$ was tested in vitro on breast cancer cells, first in one- and two-photon microscopy, which allowed for visualization of their cell internalization, then in twophoton photodynamic therapy. While being non-toxic in the dark and, more importantly, under daylight exposition, dendrimer G2 proved to be very efficient cell death inducer only under two-photon irradiation in the NIR.
\end{abstract}

\footnotetext{
[a] Dr A. Sourdon, Dr O. Mongin

Univ Rennes, CNRS, ISCR (Institut des Sciences Chimiques de Rennes), UMR 6226, F-35000 Rennes, France.

E-mail: olivier.mongin@univ-rennes1.fr

[b] Dr M. Blanchard-Desce

Univ. Bordeaux, ISM (CNRS-UMR 5255), 33405 Talence, France.

E-mail: mireille.blanchard-desce@u-bordeaux.fr

[c] Dr M. Gary-Bobo, Dr M. Maynadier, Dr M. Garcia Institut des Biomolécules Max Mousseron, UMR CNRS-UM-ENSCM 5247, UFR des Sciences Pharmaceutiques et Biologiques, 15 Avenue Charles Flahault, 34093 Montpellier Cedex 5, France.

[d] Dr J.-P. Majoral, Dr A.-M. Caminade

Laboratoire de Chimie de Coordination du CNRS,

205 route de Narbonne, BP 44099, F-31077 Toulouse Cedex 4, France

[e] Dr J.-P. Majoral, Dr A.-M. Caminade

LCC-CNRS, Université de Toulouse, CNRS

31013 Toulouse, France
}

Supporting information for this article is given via a link at the end of the document. It contains 2PA and 1PA spectra of dendrimers and corresponding dye.

\section{Introduction}

Photodynamic therapy (PDT) is a clinical treatment used in oncology for the treatment of certain types of tumors including esophagus, skin, bladder and non-small cell lung carcinomas, as well as in ophthalmology for the treatment of age-related macular degeneration (ARMD) ${ }^{[1]}$ PDT is based on the activation by light of photosensitizers; non-toxic in the absence of light excitation, a photosensitizer is able upon excitation by a laser source, to generate singlet oxygen and/or other reactive oxygen species (ROS), which leads to the destruction of the targeted tissues. ${ }^{[2]}$

The use of a two-photon excitation (2PE) offers several advantages for PDT, especially for the treatment of small areas, such as small solid tumors. ${ }^{[3]}$ These include the intrinsic threedimensional resolution allowed by $2 \mathrm{PE}$, offering the ability for highly spatially resolved excitation as well as increasing penetration depth in tissues thanks to the use of near infra-red (NIR) light. ${ }^{[4]}$ Yet, in order to achieve efficient treatments, optimized 2P photosensitizers (2PP) - i.e., combining very large 2PA cross-sections in the biological spectral window (700-1000 $\mathrm{nm}$ ) and high singlet oxygen (or ROS production) quantum yields - are required. In addition, if the 2PP remains fluorescent, in vitro monitoring is allowed, paving the way to theranostics applications. ${ }^{[3]}$ Most of the current clinical or preclinical photosensitizers are porphyrin derivatives, such as porfimer sodium (Photofrin) and verteporfin (Visudyne). As model tetraphenylporphyrin (TPP, $12 \mathrm{GM}$ ), ${ }^{[5]}$ these compounds exhibit high singlet oxygen quantum yields, significant fluorescence but low 2PA cross sections ( $10 \mathrm{GM}$ and $50 \mathrm{GM}$, respectively) in the near infra-red (NIR). ${ }^{\left[{ }^{6]}\right.}$ Giant 2PA cross-sections have been obtained with expanded porphyrins, ${ }^{[7]}$ conjugated porphyrin dimers, trimers and oligomers, ${ }^{[8]}$ planarized fused or bridged porphyrins $^{[9]}$ and supramolecular assemblies, ${ }^{[8 a, 10]}$ however at the expense of a strong modification of the other photophysical properties. In particular, it often leads to decrease or suppression of fluorescence and onset of residual one-photon absorption (1PA) overlapping with the 2PA band located in the NIR region. The huge gain in $2 P A$ response therefore results in the loss of some of the intrinsic advantages of selective 2PA, in particular of the 3D confinement of excitation and therefore spatial resolution in laser-assisted tumor resection. 
To increase the 2PA cross-sections (while avoiding one-photon absorption at the same wavelength) and still retain the excellent photosensitization and luminescence properties of the porphyrins, different systems have been designed, such as symmetrically or dissymmetrically $\pi$-extended phosphorescent metalloporphyrins, ${ }^{[11]}$ as well as dendritic antenna systems based on resonant energy transfer (FRET) from peripheral $2 \mathrm{P}$ absorbers towards a single porphyrin core ${ }^{[12]}$ and "semidisconnected" assemblies with a weak conjugation between $2 \mathrm{P}$ absorbing dendrons and a porphyrin core, ${ }^{[13]}$ or between a central 2PA unit and peripheral porphyrins. ${ }^{[14]}$ FRET between $2 \mathrm{P}$ absorbers and porphyrinic photosensitizers could also be achieved without covalent architectures by coencapsulating them within silica nanoparticles. ${ }^{[15]}$ Other types of nanoparticles based on energy transfer have been designed, including quantum dot-porphyrin ${ }^{[16]}$ and quantum dot-phthalocyanine ${ }^{[17]}$ conjugates and porphyrin-doped conjugated polymers. ${ }^{[18]}$

Non-porphyrinic 2P absorbing photosensitizers have also been developed, ${ }^{[19]}$ among which should be mentioned quadrupolar chromophores substituted with heavy atoms such as bromine or iodine, ${ }^{[20]}$ which leads to efficient intersystem crossing and singlet oxygen generation quantum yields but concomitantly to vanishing fluorescence. We have previously developed alternative $2 \mathrm{P}$ fluorescent photosensitizers based on bananashaped quadrupolar systems, that combine large 2PA crosssections and significant singlet oxygen quantum yields, while maintaining fair fluorescence quantum yields. ${ }^{[21]}$ These symmetric photosensitizers were covalently incorporated within mesoporous silica nanoparticles for efficient two-photon photodynamic therapy of solid tumors. ${ }^{[4 e, 4]}$

As an alternative to these hard nanoparticles, our aim was to develop soft and monodisperse fully organic nanodots by gathering quadrupolar $2 \mathrm{P}$ photosensitizers in phosphorus-based dendrimer architectures, and to graft at their surface watersolubilizing groups. Among the major advantages of phosphorus-based dendrimers ${ }^{[22]}$ are their low toxicity ${ }^{[23]}$ and their accessibility for both inner and surface functionalization using covalent chemistry.

This highly modular "organic nanodots" strategy was previously used successfully to obtain covalent assemblies of fluorophores, leading to luminescent nanoparticles that can outperform semiconductor quantum dots in terms of one- and two-photon brightness. ${ }^{[24]}$ These fluorescent nanodots have been proved to be of major interest for in vivo imaging. ${ }^{[25]}$

We report here the first two-photon photosensitizing nanodots and their use in photodynamic therapy.

\section{Results and Discussion}

\section{Synthesis of the graftable two-photon photosensitizer}

The photosensitizer needed for the synthesis of $\mathbf{2}-\mathbf{G}_{2}$ (Fig 1) should exhibit two different orthogonal grafting moieties, a phenol function to attach it to the dendrimeric scaffold, and an aldehyde function to continue the dendrimer synthesis and introduce water-solubilizing peripheral groups. The synthesis of this dissymmetric photosensitizer is described in Scheme 1.

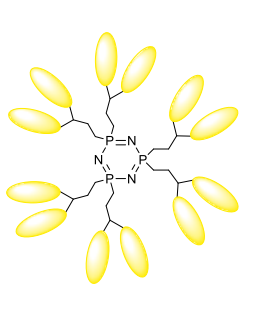

$2-G_{1}\left(N D_{12}\right)$

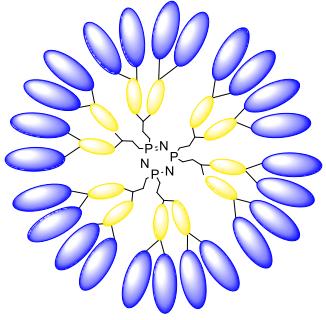

$2-G_{2}\left(W S-N D_{12}\right)$

$$
\text { : two-photon photosensitize }
$$

Figure 1. Molecular design.

The Mitsunobu condensation of $N$-ethyl- $N$-hydroxyethylaniline (1) with hydroquinone afforded $\mathbf{2 a}$. Phosphonium salts $\mathbf{2} \mathbf{b}$ and $\mathbf{6}$ were synthesized according to the procedures reported. ${ }^{[26]}$ Wittig condensations of 5-iodo-2-thiophenecarboxaldehyde $(3)^{[27]}$ with phosphonium salts $\mathbf{2 b}$ and $\mathbf{6}$ led to mixtures of stereoisomers. Their isomerization with iodine afforded $\mathbf{4 a}$ and $\mathbf{7 a}$, respectively, as pure trans isomers (Scheme 1).

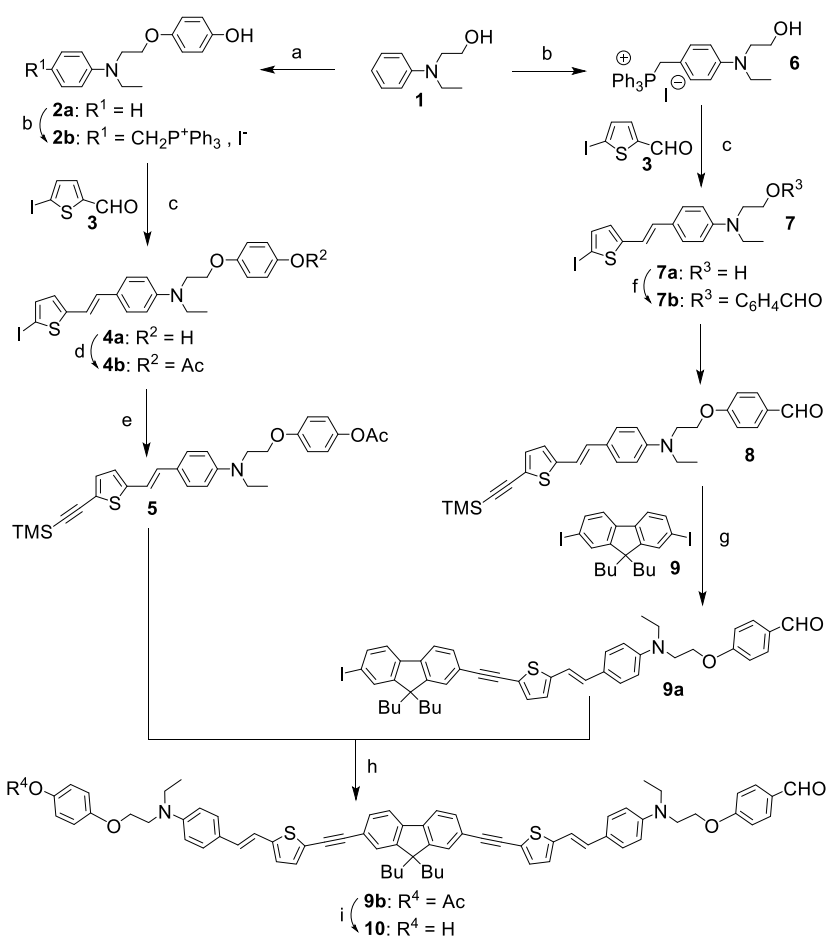

Scheme 1. Reagents and conditions. a) hydroquinone, $\mathrm{PPh}_{3}$, DIAD, THF, RT, $16 \mathrm{~h}(36 \%)$; b) $\mathrm{PPh}_{3}$, paraformaldehyde, toluene, $\mathrm{Nal}, \mathrm{H}_{2} \mathrm{O}$, acetic acid, 66h $61^{\circ} \mathrm{C}$, (83\% for 6 and $84 \%$ for $\left.2 \mathrm{~b}\right)$; c) 3 , tBuOK, anhyd $\mathrm{CH}_{2} \mathrm{Cl}_{2}, \mathrm{RT}, 16 \mathrm{~h}(50 \%$ for $7 \mathrm{a}$ and $54 \%$ for $\mathbf{4 a}$ ); d) acetyl chloride, DMAP, $\mathrm{Et}_{3} \mathrm{~N} / \mathrm{CH}_{2} \mathrm{Cl}_{2}, \mathrm{RT}, 16 \mathrm{~h}(97 \%)$; e) $\mathrm{Pd}\left(\mathrm{PPh}_{3}\right)_{2} \mathrm{Cl}_{2}$, Cul, ethynyltrimethylsilane, $\mathrm{Et}_{3} \mathrm{~N} /$ toluene, $40^{\circ} \mathrm{C}, 16 \mathrm{~h}(87 \%$ for 8 and $94 \%$ for 5); f) 4 hydroxybenzaldehyde, $\mathrm{PPh}_{3}$, DIAD, THF, RT, $16 \mathrm{~h}$ (81\%); g) 8, 9, $\mathrm{Pd}\left(\mathrm{PPh}_{3}\right)_{2} \mathrm{Cl}_{2}, \mathrm{Cul}, \mathrm{TBAF} / \mathrm{THF}, 40^{\circ} \mathrm{C}, 16 \mathrm{~h}(77 \%)$; h) 5, $\mathrm{Pd}\left(\mathrm{PPh}_{3}\right)_{2} \mathrm{Cl}_{2}$, Cul, TBAF/THF, $40^{\circ} \mathrm{C}, 16 \mathrm{~h}(70 \%)$; i) $\mathrm{NaOH}, \mathrm{EtOH} / \mathrm{THF}, \mathrm{RT}, 20$ $\min (84 \%)$. 


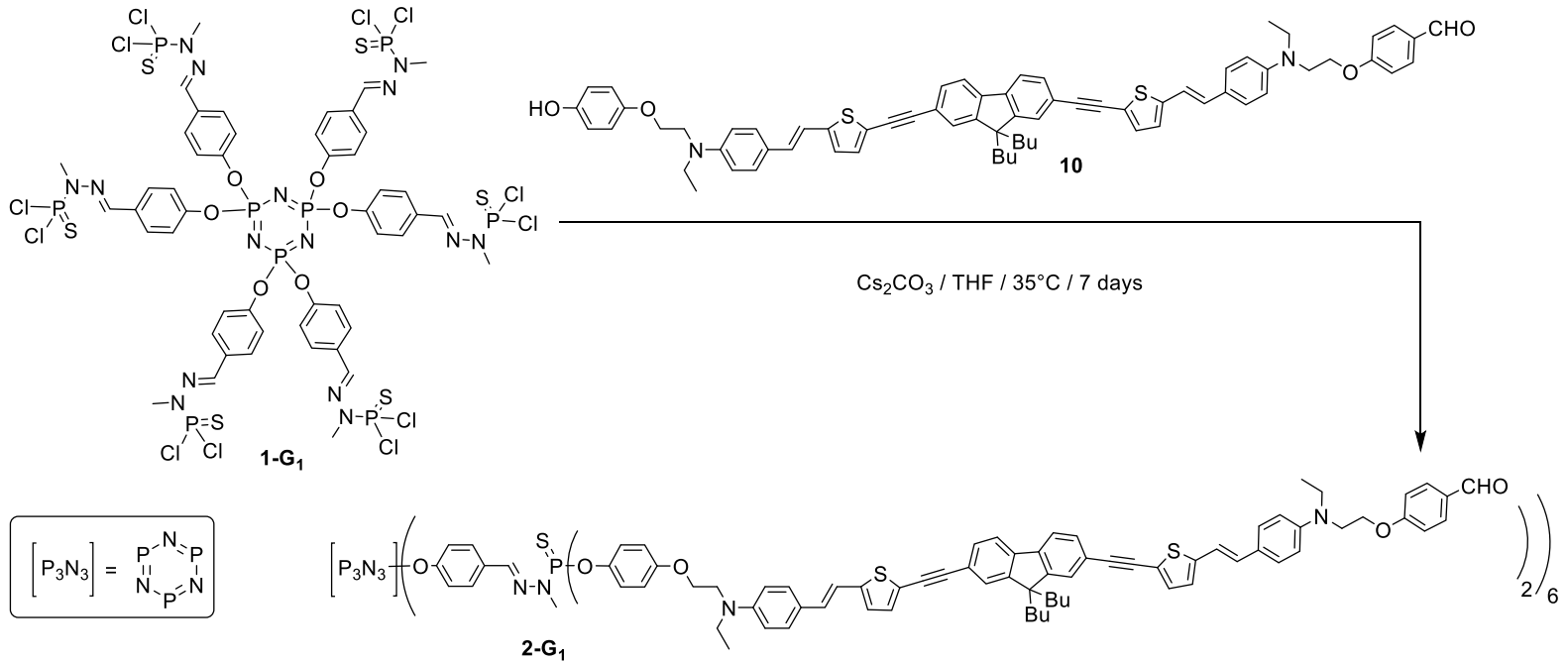

Scheme 2. Synthesis of spherical dendrimer $\mathbf{2}-\mathbf{G}_{1}$.

On one hand, the phenol function of $\mathbf{4 a}$ was esterified with acetyl chloride, giving $\mathbf{4 b}$, which was reacted with ethynyltrimethylsilane in a Sonogashira coupling to afford $\mathbf{5}$, and on the other hand, Mitsunobu condensation of $7 \mathbf{a}$ with 4hydroxybenzaldehyde gave $\mathbf{7 b}$, which was also coupled with ethynyltrimethylsilane, leading to $\mathbf{8}$. Finally, graftable chromophore $\mathbf{1 0}$ was obtained as a single $E, E$-stereoisomer, from 9,9-dibutyl-2,7-diiodo-9H-fluorene $(9)^{[28]}$ by means of two successive Sonogashira couplings with 8 and $\mathbf{5}$, followed by saponification of the acetate protective group (Scheme 1).

The synthesis of the spherical first generation dendrimer $\mathbf{2}-\mathbf{G}_{\mathbf{1}}$ was carried out by grafting 12 equivalents of the 2PA chromophore $\mathbf{1 0}$ in the presence of caesium carbonate, to the $\mathrm{P}(\mathrm{S}) \mathrm{Cl}_{2}$ end groups of the first generation phosphorous

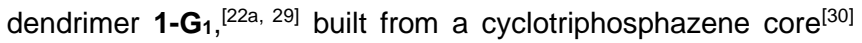
(Scheme 2). The substitution of the twelve chlorine atoms of 1$\mathbf{G}_{1}$ with such a bulky substituent was slow and needed 7 days to go to completion. This reaction was monitored by ${ }^{31} \mathrm{P}$ NMR which shows a total disappearance of the singlet at $\delta=62.3$ ppm corresponding to the phosphorus $P_{1}$ in $\mathbf{1 -} \mathbf{G}_{1}$ on behalf of a new singlet at $\delta=64.3 \mathrm{ppm}$ due to the phosphorus $P_{1}$ in $\mathbf{2}-\mathrm{G}_{1}$. An intermediate signal observed at $\delta=69.3 \mathrm{ppm}$ and corresponding to the monosubstitution (i.e. $\mathrm{P}(\mathrm{S}) \mathrm{ClOAr}$ ) totally disappears when the reaction is over. The second step consisted in the condensation of 12 equivalents of the phosphorhydrazide $\mathbf{1 1}$ with the aldehyde functions of $\mathbf{2}-\mathbf{G}_{1}$ in chloroform at room temperature, and afforded the second generation of the dendrimer $\mathbf{1}-\mathbf{G}_{2}$ (Scheme 3 ).

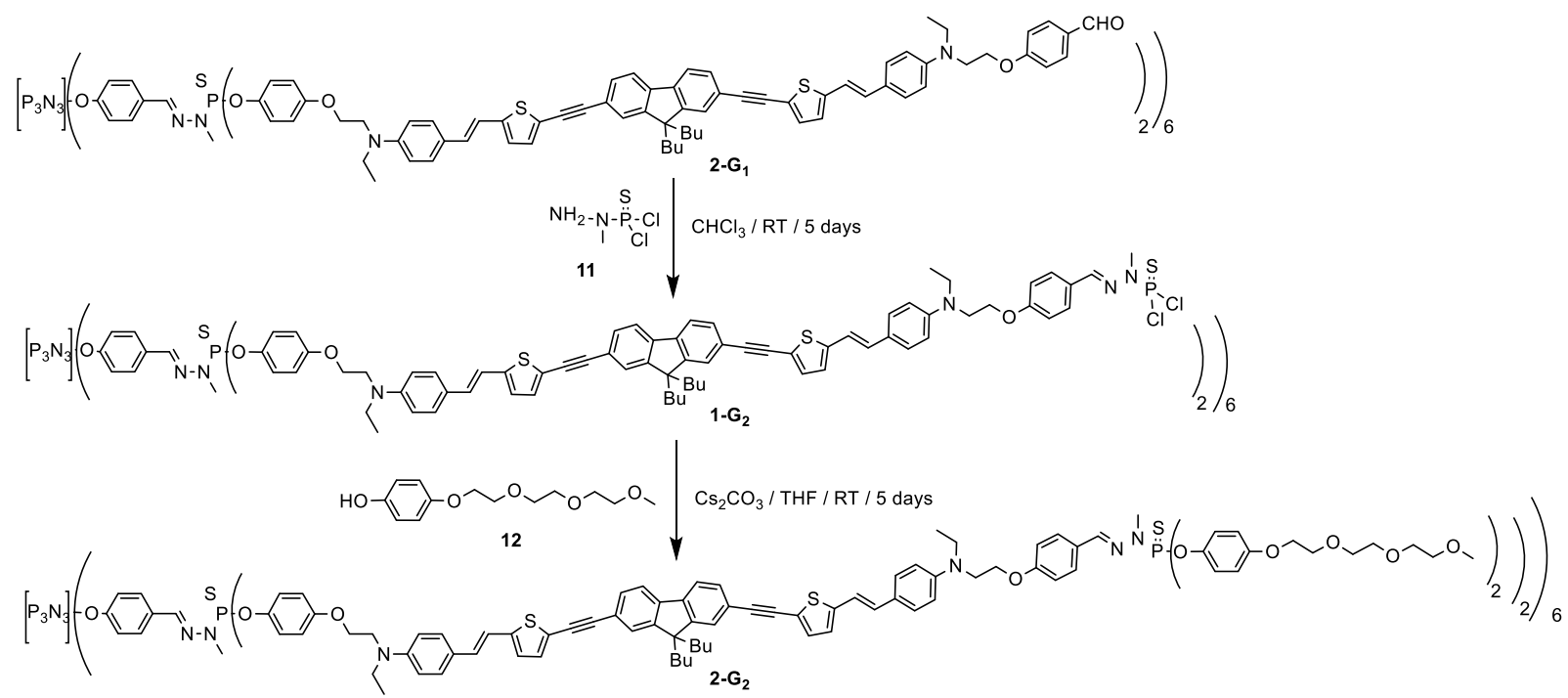

Scheme 3. Synthesis of spherical dendrimer $\mathbf{2}-\mathbf{G}_{2}$. 
Table 1. Photophysical properties of compound $10,2-G_{1}$ and $2-G_{2}$ in THF.

\begin{tabular}{|c|c|c|c|c|c|c|c|c|}
\hline Cpd & $\begin{array}{l}\lambda_{\text {abs }} \\
/ \mathrm{nm}\end{array}$ & $\begin{array}{c}\varepsilon_{\max }{ }^{[a]} \\
/ \mathrm{M}^{-1} \cdot \mathrm{cm}^{-1}\end{array}$ & $\begin{array}{c}\varepsilon_{\max } / \mathrm{n}^{[\mathrm{b}]} \\
/ \mathrm{M}^{-1} \cdot \mathrm{cm}^{-1}\end{array}$ & $\begin{array}{l}\lambda_{\mathrm{em}} \\
/ \mathrm{nm}\end{array}$ & $\begin{array}{l}\text { Stokes shift } \\
/ 10^{3} \mathrm{~cm}^{-1}\end{array}$ & $\Phi_{\mathrm{F}}[\mathrm{c}]$ & $\tau / \mathrm{ns}^{[\mathrm{d}]}$ & $\Phi_{\Delta}{ }^{[e]}$ \\
\hline 10 & 434 & $1.210^{5}$ & $1.210^{5}$ & 544 & 4.66 & 0.51 & 1.3 & 0.16 \\
\hline $2-G_{1}$ & 433 & $1.210^{6}$ & $1.010^{5}$ & 547 & 4.81 & 0.50 & $\begin{array}{c}\tau 1=0.56 ; \mathrm{n} 1=63 \% \\
\tau 2=1.5 ; \mathrm{n} 2=37 \%\end{array}$ & 0.10 \\
\hline $2-G_{2}$ & 434 & $1.010^{6}$ & $8.310^{4}$ & 560 & 5.18 & 0.21 & $\begin{array}{c}\tau 1=0.52 ; \mathrm{n} 1=66 \% \\
\tau 2=1.4 ; \mathrm{n} 2=34 \%\end{array}$ & 0.07 \\
\hline
\end{tabular}

[a] Molar extinction coefficient. [b] Molar extinction coefficient per chromophoric subunit [c] $\Phi_{\mathrm{F}}=$ fluorescence quantum yield, using as a standard quinine bisulfate $\left(\Phi_{\mathrm{F}}=0.546\right)$ in $0.5 \mathrm{M}$ aq H $\mathrm{H}_{2} \mathrm{SO}_{4}$. [d] Fluorescence lifetime. [e] $\Phi_{\Delta}=$ singlet oxygen formation quantum yield determined relative to tetraphenylporphyrin in methylene chloride $\left(\Phi_{\Delta}[\mathrm{TPP}]=0.60\right.$ in methylene chloride).

The reaction was monitored by ${ }^{1} \mathrm{H}$ NMR, its completion being characterized by the total disappearance of the aldehyde singlet. The ${ }^{31} \mathrm{P}$ NMR spectrum of $2-\mathbf{G}_{1}$ consists of three singlets $\delta=8.6$ ppm for the core, $\delta=63.3 \mathrm{ppm}$ for $\mathrm{P}_{1}, \delta=64.4 \mathrm{ppm}$ for the newly grafted phosphorus $\mathrm{P}_{2}$.

The next step involved the grafting of 24 equivalents of the monodisperse triethyleneglycol chain 12 on $1-G_{2}$ to improve solubility in water, affording dendrimer $\mathbf{2}-\mathbf{G}_{2}$ (Scheme 3 ). Here again, the reaction was monitored by ${ }^{31} \mathrm{P} N M R$. Almost no change occurs for the signal corresponding to the core, but we observed the total disappearance of the singlet at $\delta=63.4 \mathrm{ppm}$ corresponding to the phosphorus $P_{2}$ in $\mathbf{2}-\mathbf{G}_{1}$ on behalf of a new singlet, slightly deshielded. An overlap occurs for the signals of phosphorus $\mathrm{P}_{1}$ and $\mathrm{P}_{2}$ at $\delta=64.6 \mathrm{ppm}$. To ascertain the full substitution or condensation, we used in all cases a slight excess of reagents $(10 \%)$, which was relatively easy to eliminate by washings.

\section{One photon absorption (1PA) and fluorescence properties}

The compared photophysical properties of $\mathbf{1 0}, \mathbf{2}-\mathbf{G}_{\mathbf{1}}$, and $\mathbf{2}-\mathbf{G}_{\mathbf{2}}$ in THF are shown in Table 1 and their absorption and emission spectra are represented in Fig 2. THF was chosen as a common solvent as all three compounds are soluble in this solvent. All compounds exhibit an intense absorption band from the near UV to the blue visible range and an emission band from the green visible range to the yellow visible range (Fig 2). Dendrimers also show strong one-photon absorption in the UV

The low-energy absorption band located at $434 \mathrm{~nm}$ can be ascribed to a periphery-to-core intramolecular charge transfer transition, characteristic of bis-donor quadrupolar dyes built from a fluorene core. ${ }^{[31]}$ We note a broadening on the high energy side for organic nanodots $\mathbf{2}-\mathbf{G}_{\mathbf{1}}$ and even more for $\mathbf{2}-\mathbf{G}_{\mathbf{2}}$ as compared to the isolated dye $\mathbf{1 0}$ in solution (Fig.2). This can be related to the residual absorption of the dendrimeric backbone. In addition, a hypochromic effect is observed: the extinction coefficients of the chromophoric building blocks are reduced by about $\mathbf{1 7} \%$ for $\mathbf{2}-\mathbf{G}_{\mathbf{1}}$ and $\mathbf{3 0} \%$ for $\mathbf{2}-\mathbf{G}_{\mathbf{2}}$ (Table $\mathbf{1}$ ).

This suggests that different conformations or relative positioning of the dyes within the dendrimeric architecture might occur, in particular in the case of $\mathbf{2}-\mathbf{G}_{2}$, suggesting that partial interactions and more compact arrangement might occur in that case.

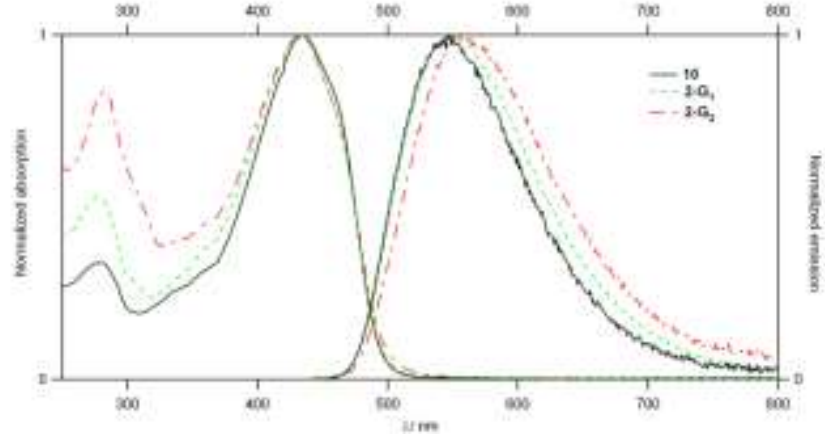

Figure 2. Normalized absorption and emission spectra of compounds 10, 2-G and $\mathbf{2}-\mathrm{G}_{2}$, in THF.

Dye 10 exhibits a significant singlet oxygen quantum yield as well as a reasonable fluorescence quantum yield (Table 1), as was initially required for allowing both therapy (by photosensitized production of singlet oxygen) and monitoring (by fluorescence imaging).

The grafting of photosensitizers on the dendrimeric scaffold (from 10 to $2-G_{1}$ ) leads to a slight red shift and broadening of the emission (Fig 2), in relation with an increase of the polarity produced by polarizable environment produced by the dendrimeric scaffold and the closeness of adjacent quadrupolar dyes. ${ }^{[32]}$ Interestingly, in spite of the confinement of the dyes chromophores in a reduced volume, 2-G $\mathbf{G}_{1}$ maintains the same fluorescence quantum yield than the isolated dye 10. This indicates that no significant through-space interchromophoric interactions which would lead to fluorescence quenching occurs within 2-G 1 . At opposite, fluorescence quenching of fluorescence is often observed when widespread fluorescent dyes (such as Nile red, dioxaborine...) are grafted in close proximity onto a similar dendritic architecture. ${ }^{[33]}$ In contrast, rigid extended dendrimers where quadrupolar subunits are directly connected by triphenylamine nodes were reported to show strong throughbond coupling leading to cooperative enhancement of 2PA and preservation of high fluorescence quantum yield. ${ }^{[34]}$ In comparison, the design of dendrimers $\mathbf{2}-\mathbf{G}_{\mathbf{1}}$ and $\mathbf{2}-\mathbf{G}_{\mathbf{2}}$ does not allow through-bond coupling between dye subunits due to the 
presence of alkyl linkers $\left(\mathrm{CH}_{2}-\mathrm{CH}_{2}\right)$ between conjugated moieties.

We also note that the fluorescence decay is biexponential most probably in relation with conformational flexibility of the dye. Such phenomenon was not observed in the case of ultra-bright organic nanodots confining more rigid and shorter quadrupolar dyes. ${ }^{[24 a]}$

A more pronounced red shift of the emission band is observed with $\mathbf{2}-\mathbf{G}_{2}$, indicating that the addition of a water-solubilizing layer increases the polarity of the environment of the buried chromophores. The most prominent feature is a significant decrease of the fluorescence quantum yield. This behavior indicates that competing deactivation process takes place and/or interaction between the dyes occurs within dendrimer $\mathbf{2}-\mathbf{G}_{2}$ compared to $\mathbf{2}-\mathbf{G}_{\mathbf{1}}$. Most probably, the presence of the hydrophilic layer created by the TEG surface moieties produces a different external environment which may induce different organization of the dendritic backbone, as discussed earlier, and favor interchromophoric ground-state interactions that are deleterious to fluorescence.

The singlet oxygen production $\left(\Phi_{\Delta}\right)$ is also reduced in dendrimers $\mathbf{2}-\mathbf{G}_{1}$ (by $37 \%$ ) and $\mathbf{2}-\mathbf{G}_{\mathbf{2}}$ (by $56 \%$ ) as compared to isolated dye 10 . We note that this progression is similar to the decrease in extinction coefficient and could be related to the different conformations and possible interactions of the dyes within the dendrimeric backbone. This may also originate from the hindered access of dissolved dioxygen molecules to the buried dyes subunits in dendrimer $\mathbf{2}-\mathbf{G}_{2}$, the TEG surface moieties creating a barrier to the diffusion of $\mathrm{O}_{2}$ molecules.

\section{Solvatochromism}

Fig 3 and 4 illustrate the dependence of the absorption and emission properties of dye $\mathbf{1 0}$ and soft organic nanodot $\mathbf{2}-\mathbf{G}_{\mathbf{2}}$ on solvent polarity. Increasing the solvent polarity induces a slight red shift of the absorption band and a marked bathochromic shift of the emission band as clearly illustrated in Fig $\mathbf{3}$ for $\mathbf{1 0}$ and Fig 4 for $\mathbf{2}-\mathbf{G}_{2}$. This is consistent with symmetry breaking occurring in the excited state prior to emission. ${ }^{[35]}$

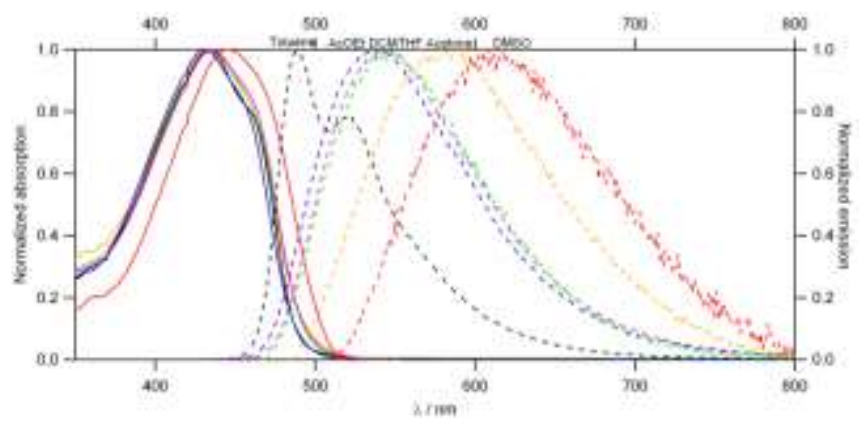

Figure 3. Normalized absorption and emission spectra of quadrupolar dye $\mathbf{1 0}$ in solvents of different polarities.

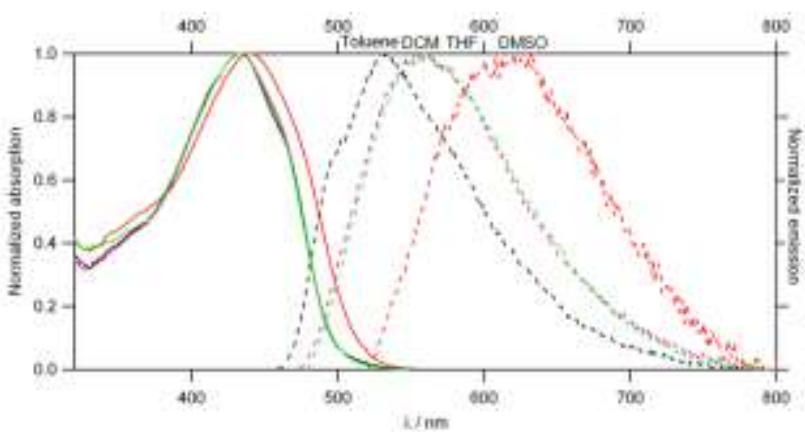

Figure 4. Normalized absorption and emission of dendrimer $\mathbf{2}-\mathbf{G}_{\mathbf{2}}$ in solvents of different polarities.

However, it appears clearly that the emission of nanodot $\mathbf{2}-\mathbf{G}_{\mathbf{2}}$ in a low polarity solvent such as toluene is strongly red-shifted in comparison with the emission of $\mathbf{1 0}$ in the same solvent, which confirms that the dendrimeric scaffold and the triethyleneglycol chains do influence the polarity of the environment of the chromophores by creating a cybotactic region reminiscent of that of ethyl acetate.

\section{Two-photon absorption}

2PA measurements were conducted by investigating the twophoton excited fluorescence (2PEF) of dendrimers $2-G_{1}$ and 2$\mathrm{G}_{2}$ in THF. The 2PA spectrum of monomeric dye $\mathbf{1 0}$ was also determined for comparison. The quadratic dependence of the 2PEF signal on the excitation intensity was checked for each data point, indicating that no photodegradation or saturation occurs.

As expected from its symmetric quadrupolar type structure, dye $\mathbf{1 0}$ shows an intense 2PA band located around $720 \mathrm{~nm}$ (with maximum 2PA cross-section of about $1900 \mathrm{GM}$ ) which can be ascribed to a higher energy excited state which is strongly twophoton allowed (see figure S2). Yet the lowest-energy excited state also leads to significant 2PA response at $870 \mathrm{~nm}$ (Table 2), indicating that this state is both one-photon and two-photon allowed. This effect can be attributed to a breaking of centrosymmetry induced by the dissymmetrical environment of the dye. Indeed, dye 10 bears an alkoxybenzaldehyde moiety only on one side. The presence of this dipolar unit $(\mu>5 D)^{[36]}$ generates a local electric field which in turns affects the polarization of the quadrupole thus breaking its centrosymmetry. This effect is clearly noticeable, in agreement with the reported strong effect of local electric field on the 2PA of dyes. ${ }^{[37]}$ Along this line, we also note that the two-photon allowed excited state is also slightly onephoton allowed (see Figure S2). Hence the breaking of centrosymmetry results in multiple absorption bands (and thus broader response) as compared to purely symmetrical quadrupolar chromophores. 
Table 2. Two-photon absorption data of compounds $10,2-\mathbf{G}_{1}, \mathbf{2 - G _ { 2 }}$ in THF.

\begin{tabular}{|c|c|c|c|c|c|c|c|c|c|c|c|}
\hline Cpd & $\begin{array}{c}2 \lambda_{1 \mathrm{PA}}{ }^{\max } \\
/ \mathrm{nm}\end{array}$ & $\begin{array}{c}\sigma_{2} \\
/ \mathrm{GM}^{[\mathrm{a}]}\end{array}$ & $\begin{array}{l}\sigma_{2} / \mathrm{n} \\
/ \mathrm{GM}\end{array}$ & $\begin{array}{l}\lambda_{2 \mathrm{PA}^{\max 1}} \\
/ \mathrm{nm}^{[\mathrm{b}]}\end{array}$ & $\begin{array}{l}\sigma_{2}{ }^{\max 1} \\
/ \mathrm{GM}{ }^{[\mathrm{c}]}\end{array}$ & $\begin{array}{c}\sigma_{2}{ }^{\max 1 / n} \\
/ \mathrm{GM}\end{array}$ & $\begin{array}{l}\lambda_{2 \mathrm{PA}}{ }^{\max 2} \\
/ \mathrm{nm}^{[\mathrm{b}]}\end{array}$ & $\begin{array}{l}\sigma_{2}{ }^{\max 2} \\
/ \mathrm{GM}{ }^{[\mathrm{c}]}\end{array}$ & $\begin{array}{c}\sigma_{2}{ }^{\max 2} / \mathrm{n} \\
/ \mathrm{GM}\end{array}$ & $\begin{array}{c}\sigma_{2} \Phi_{\mathrm{F}} \\
/ \mathrm{GM}^{[\mathrm{d}]}\end{array}$ & $\begin{array}{c}\sigma_{2} \Phi_{\Delta} \\
/ \mathrm{GM}^{[\mathrm{e}]}\end{array}$ \\
\hline 10 & 868 & 680 & 680 & 820 & 1240 & 1240 & 720 & 1890 & 1890 & 960 & 300 \\
\hline $2-G_{1}$ & 866 & 6050 & 504 & 820 & 11200 & 933 & 730 & 19200 & 1517 & 9600 & 1920 \\
\hline
\end{tabular}

[a] $2 \mathrm{PA}$ cross section at $2 \lambda_{1 \mathrm{PA}}{ }^{\max }$. [b] Maximum 2PA wavelength. [c] $2 \mathrm{PA}$ cross section at $\lambda_{2 \mathrm{PA}}{ }^{\max }$. [d] $2 \mathrm{P}$-brightness at $\lambda_{2 \mathrm{PA}}{ }^{\max 2}$. [e] Figure of merit of the $2 \mathrm{P}$ induced singlet oxygen generation at $\lambda_{2 \mathrm{PA}}{ }^{\max 2} .1 \mathrm{GM}=10^{-50} \mathrm{~cm}^{4}$.s.photon ${ }^{-1}$.

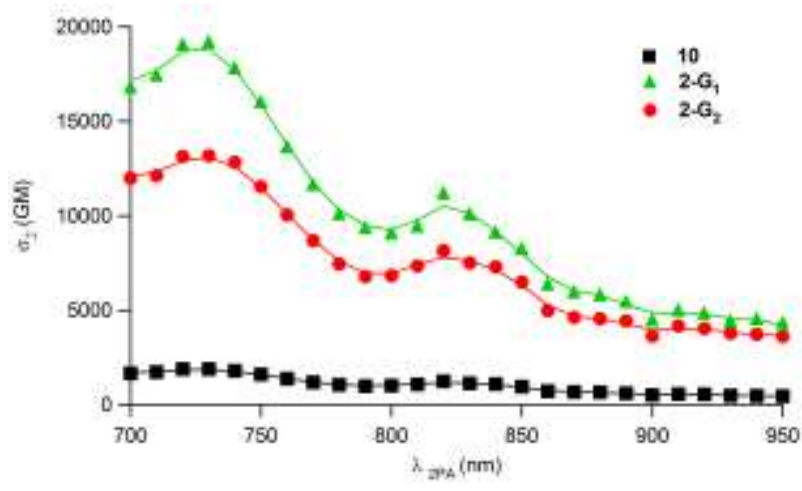

Figure 5. 2PA spectra of $\mathbf{1 0}, \mathbf{2}-\mathbf{G}_{1}, \mathbf{2}-\mathrm{G}_{\mathbf{2}}$ in THF (with solid curves as guides for the eyes only).

Dendrimers $\mathbf{2}-\mathbf{G}_{1}$ and $\mathbf{2}-\mathbf{G}_{2}$ also show the same intense $2 \mathrm{PA}$ bands located at 820 and $730 \mathrm{~nm}$ as clearly seen from Fig. 5 , leading to very large 2PA responses at $730 \mathrm{~nm}$ (up to $19200 \mathrm{GM}$ for $\mathbf{2}-\mathbf{G}_{1}$ and $13200 \mathrm{GM}$ for $\mathbf{2}-\mathbf{G}_{2}$ ). Yet, we note that the molecular response of each individual dye is affected by the confinement and the modification of the environment induced by the dendrimeric scaffold (see Figure S1). As seen from Table 2, a reduction of the 2PA cross-sections per chromophoric subunit of about $20-25 \%$ (resp. $40-45 \%$ ) is observed at $870 \mathrm{~nm}, 820 \mathrm{~nm}$ and $730 \mathrm{~nm}$ for $\mathbf{2}-\mathbf{G}_{1}$ (resp. $\mathbf{2}-\mathbf{G}_{2}$ ). Addition of the water-solubilizing groups leads to a further decrease of about $30 \%$ of the 2PA crosssections for dendrimer $\mathbf{2}-\mathbf{G}_{2}$ as compared to $\mathbf{2}-\mathbf{G}_{\mathbf{1}}$.

This decrease is reminiscent of the decrease noted in one-photon absorption, although the trend is even stronger. This once again confirms that different positioning and possibly partial ground-state interactions between dye subunits occur in the dendrimeric architecture, leading to both decrease of 1PA and 2PA.

Yet we note that dendrimers $\mathbf{2}-\mathbf{G}_{1}$ and $\mathbf{2}-\mathbf{G}_{2}$ retain very large $2 \mathrm{PA}$ cross-sections at $730 \mathrm{~nm}$ ( 19200 and $13200 \mathrm{GM}$ respectively) and maintain high 2PA response over $5000 \mathrm{GM}$ down to $900 \mathrm{~nm}$. This effect can be ascribed to symmetry breaking (also noted in dendrimers $\mathbf{2}-\mathbf{G}_{1}$ and $\mathbf{2}-\mathbf{G}_{2}$, see Figure $\mathbf{S} 3$ and $\mathbf{S} 4$ ) promoted by the presence of dipolar moieties in close proximity. This results in a broadening of the 2PA spectrum, which is of interest for biological applications and use in two-photon bioimaging.

\section{Investigation of cell internalization by fluorescence imaging}

Based on its properties (1PA and 2PA responses, fluorescence properties and presence of water-solubilizing surface groups), dendrimer $\mathbf{2}-\mathbf{G}_{2}$ was tested in one- and two-photon excited fluorescence (2PEF) cell imaging. In order to analyze its penetration in cancer cells, dendrimer $\mathbf{2}-\mathbf{G}_{\mathbf{2}}$ was incubated for $24 \mathrm{~h}$ with MCF-7 human breast cancer cells, whose nuclei were stained with Hoechst 33342 as described in the experimental section. As shown in Figure 6, confocal fluorescence microscopy showed that $\mathbf{2}-\mathbf{G}_{2}$ is efficiently internalized.
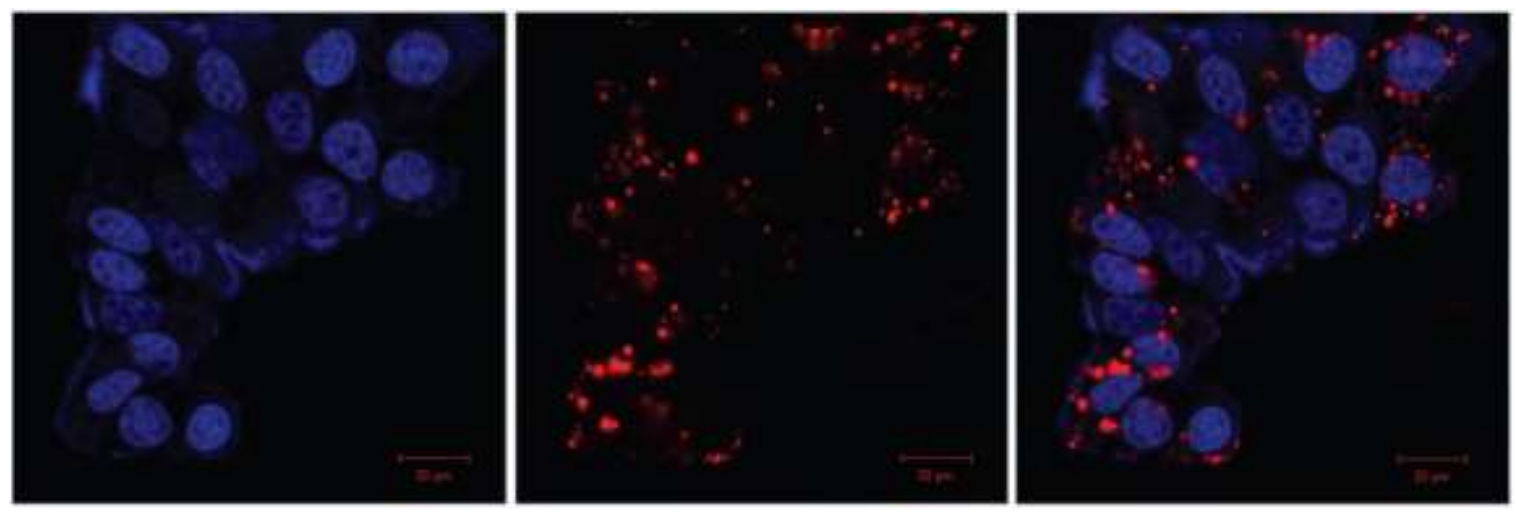

Figure 6. Nuclear marker (left, excited at $405 \mathrm{~nm}$ ), 2-G2 (middle, excited at $458 \mathrm{~nm}$ ) and merge (right) confocal microscopy images of living MCF-7 human breast cancer cells, incubated for $24 \mathrm{~h}$ with $50 \mu \mathrm{g} \cdot \mathrm{mL}^{-1} 2-\mathrm{G}_{2}$. 


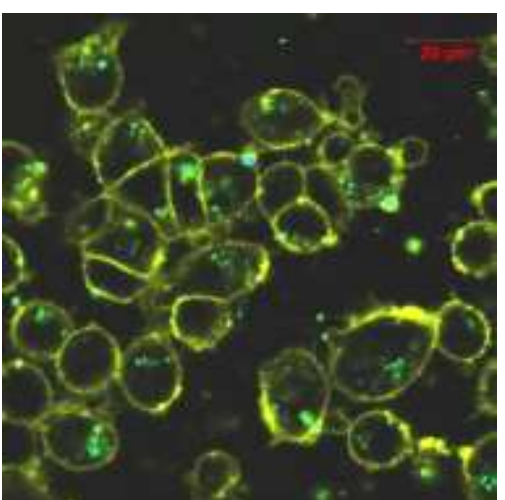

Figure 7. Merged multiphoton confocal microscopy images of living MCF-7 breast cancer cells, incubated for $3 \mathrm{~h}$ at $37^{\circ} \mathrm{C}$ with $50 \mu \mathrm{g} \cdot \mathrm{mL}^{-1} 2-\mathrm{G}_{2}$ excited at $750 \mathrm{~nm}$ (green) and membrane marker (yellow).

The cell distribution of dendrimer $\mathbf{2}-\mathbf{G}_{\mathbf{2}}$ was also investigated by co-staining with a membrane marker. MCF-7 breast cancer cells were incubated for $3 \mathrm{~h}$ with $\mathbf{2}-\mathbf{G}_{\mathbf{2}}$, then plasma membranes were stained with CellMask as described in the experimental section (Fig 7). Merged images of membranes and $\mathbf{2}-\mathbf{G}_{2}$ showed that NDs were efficiently internalized after $3 \mathrm{~h}$ of incubation. The semi-circular shape of NDs localization in cell suggests that $\mathbf{2}-\mathbf{G}_{2}$ molecules are located in lysosomes.

Hence, $\mathbf{2}-\mathbf{G}_{\mathbf{2}}$ is internalized by cancer cells. The amount of internalized dendrimers depends on the incubation time. We found that more dendrimers were present in cells after $24 \mathrm{~h}$ incubation (Fig 6) than after $3 \mathrm{~h}$ (Fig 7).

In all cases, internalization occurs and $\mathbf{2}-\mathbf{G}_{2}$ was found to be nontoxic at $50 \mu \mathrm{g} \cdot \mathrm{mL}^{-1}$ without irradiation (not shown). An incubation time of $20 \mathrm{~h}$ was thus selected for PDT experiments.

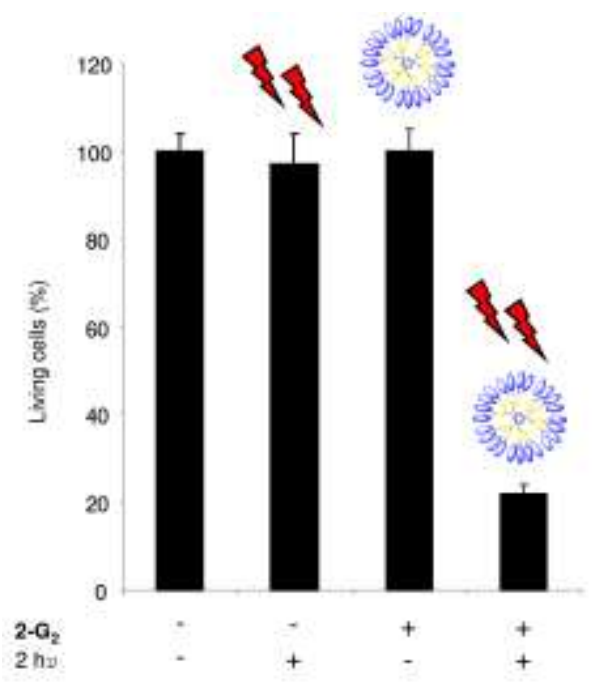

Figure 8. 2PE-PDT efficiency on MCF-7 breast cancer cells incubated or not (control) for $20 \mathrm{~h}$ with $50 \mu \mathrm{g} . \mathrm{mL}^{-1}$ of dendrimer $2-\mathrm{G}_{2}$ and then irradiated or not (control) at $760 \mathrm{~nm}$ for $3 \times 1.57 \mathrm{~s}$. Data are mean $\pm \mathrm{SD}$ of 3 experiments.
Two-photon excited photodynamic therapy (2PE-PDT) experiments

2PE-PDT experiments were performed on MCF-7 breast cancer cells incubated with or without $\mathbf{2}-\mathbf{G}_{\mathbf{2}}\left(50 \mu \mathrm{g} . \mathrm{mL}^{-1}\right)$ for 20 hours. After incubation, cells were washed, maintained in fresh culture medium and then submitted or not to laser irradiation. Twophoton irradiation was performed on a confocal microscope equipped with a femtosecond pulsed Ti:sapphire laser. The laser beam was focused using a microscope objective lens (10X, NA 0.4). Cells were irradiated at $760 \mathrm{~nm}$ by 3 scans of $1.57 \mathrm{sec}$ each at an average power of $80 \mathrm{~mW}$. The surface of the scanned areas was $1.5 \times 1.5 \mathrm{~mm}^{2}$ (mean energy of $16.6 \mathrm{~J} \mathrm{~cm}^{-2}$ ). Two days after irradiation, the percentage of living cells was determined by MTS enzymatic assay. Results are reported in Figure $\mathbf{8}$, and $\mathbf{2}-\mathrm{G}_{2}$ was found to be non-toxic without irradiation. It was also shown that irradiation alone did not damage the cells. Hence, the photodynamic therapeutic potential of $\mathbf{2 - G _ { 2 }}$ is demonstrated, with $78 \%$ cell death under two-photon irradiation of MCF-7 cells incubated with $\mathbf{2}-\mathbf{G}_{\mathbf{2}}$. The in vitro efficiency of this compound is thus comparable to that of mesoporous silica nanoparticles (MSNs) incorporating a closely related chromophore towards the same MCF-7 cell line, these MSNs leading to $56 \%$ cell death after $4 \mathrm{~h}$ incubation time and $100 \%$ cell death after $24 \mathrm{~h}$ incubation time, followed by irradiation $(3 \mathrm{x}$ $1 \mathrm{~s})$ at the same wavelength and power. ${ }^{[4 \mathrm{e}]}$ As these MSNs had also been demonstrated to induce tumor regression $(70 \%$ decrease in tumor size) on nude mice bearing tumor xenografts upon $9 \mathrm{~min}$ of irradiation at the same wavelength (i.e. $760 \mathrm{~nm}$ ) and power, a required irradiation time of 10-20 min can be anticipated with organic dendrimer $\mathbf{2}-\mathbf{G}_{2}$ for in vivo $2 \mathrm{PE}-\mathrm{PDT}$. It should be added that 2PE-PDT drugs bearing peptides specific of tumor vasculature targeting, already led to even higher tumor regressions for deep-tissue cancer treatment on mice, with comparable irradiation times. ${ }^{[4 \mathrm{c}, 4]}$ This indicates that further surface functionalization of dendrimer $\mathbf{2}-\mathbf{G}_{2}$ with similar targeting peptides would be of major interest for PDT.

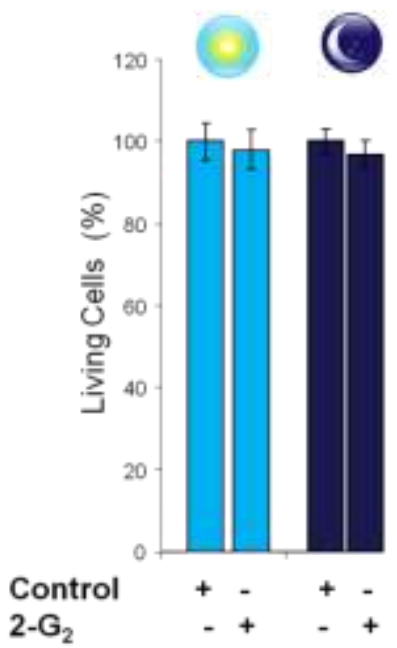

Figure 9. Absence of toxicity on MCF-7 breast cancer cells of $\mathbf{2 - \mathbf { G } _ { 2 }}$ in the dark (right) or under daylight exposition (left). 
The two-photon induced toxicity of $\mathbf{2}-\mathbf{G}_{\mathbf{2}}$ can originate from different processes including singlet oxygen production. Indeed 2-G $\mathbf{G}_{\mathbf{2}}$ displays a two-photon induced singlet oxygen generation $\left(\sigma_{2} \Phi_{\Delta}\right)$, which is 120 times larger than that of TPP (see Table 2). Yet formation of reactive oxygen species via different photoinduced processes (in particular electron transfer sensitized by quadrupolar subunits, which become strong electron donor in the excited state) may also contribute to the two-photon induced cell death.

Interestingly, no cell death was observed when the cells were exposed to daylight for 4 hours, indicating that dendrimer $\mathbf{2}-\mathbf{G}_{2}$ is nontoxic under daylight illumination conditions (Figure 9). Dendrimer $\mathbf{2}-\mathbf{G}_{\mathbf{2}}$ is thus nontoxic in the dark and even under daylight exposition. This represents an important progress in view of therapeutics as it allows circumventing side effects in current daylight. The daylight toxicity represents a common drawback of photodynamic therapy medical treatment as it requires patients to avoid direct light for a certain time. This effect can be related to the large number of UV absorbers present on the outskirt of the phosphorous dendritic backbone of 2-G , which form an effective UV-screen, avoiding excitation of the inner quadrupolar photosensitizers by UV from sunlight. At opposite, these constitutive UV absorbers are very poor $2 \mathrm{P}$ absorbers in the 700-950 nm spectral range, thus permitting $2 \mathrm{P}$ excitation of the inner quadrupolar subunits. This leads to a twophoton versus one-photon excitation on-off process (i.e. the dendritic platform is transparent to two-photon excitation in the NIR region but absorbing upon UV excitation).

\section{Conclusions}

In summary we have described a new class of dendrimeric nanoparticles for theranostics, which combine unique properties for bioimaging and anticancer therapy. These fully organic, soft, yet monodisperse nanoparticles show:

(i) high two-photon absorption in the biological spectral window, which allows highly confined and three-dimensional photoaddressing in tissues, thus limiting side damages,

(ii) large two-photon brightness, which allows fluorescent tracking in cells and investigation of cell internalization,

(iii) efficient two-photon photosensitizing properties in the NIR region leading to highly spatially controlled cell death.

In vitro experiments conducted on human breast cancer cells demonstrated these dendrimeric nanoparticles to be efficient nanomedicine tools as their distribution and penetration within cells can be efficiently monitored by fluorescence imaging, while cancer cell death can be induced efficiently and selectively upon two-photon excitation in the NIR.

Moreover they were found to be non-toxic in the dark and, more importantly, under daylight exposition, which is a major advantage in comparison with other photodynamic therapy medical treatments. The grafting of targeting functions could further improve the therapeutic promise of these nano-objects by adding to the spatial selectivity of the two-photon activation a high affinity for cancer cells. We are currently exploring this way.

\section{Experimental Section}

\section{Synthetic procedures}

General methods. All air or water-sensitive reactions were carried out under dry argon. Solvents were generally dried and distilled prior to use. Reactions were monitored by thin layer chromatography on Merck silica gel $60 \mathrm{~F}_{254}$ precoated aluminum sheets, or by NMR. Column chromatography: Merck silica gel Si 60 (40-63 $\mu \mathrm{m}, 230-400$ mesh or 63$200 \mu \mathrm{m}, 70-230 \mathrm{mesh})$. Melting points were determined on a system Kofler type WME. NMR: Bruker Avance AV $300\left({ }^{1} \mathrm{H}: 300.13 \mathrm{MHz},{ }^{13} \mathrm{C}\right.$ : $75.48 \mathrm{MHz},{ }^{31} \mathrm{P}$ : $121.58 \mathrm{MHz}$ ), in $\mathrm{CDCl}_{3}, \mathrm{CD}_{2} \mathrm{Cl}_{2}$ or DMSO-d 6 solutions; ${ }^{1} \mathrm{H}$ chemical shifts $(\delta)$ are given in ppm relative to TMS as internal standard, $J$ values in $\mathrm{Hz}$ and ${ }^{13} \mathrm{C}$ chemical shifts relative to the central peak of $\mathrm{CDCl}_{3}$ at $77.0 \mathrm{ppm},{ }^{31} \mathrm{P}$ chemical shifts relative to $85 \% \mathrm{H}_{3} \mathrm{PO}_{4}$. High and low resolution mass spectra measurements were performed at the Centre Regional de Mesures Physiques de l'Ouest (C.R.M.P.O, Rennes) using a Micromass MS/MS ZABSpec TOF instrument with EBE TOF geometry; LSIMS (Liquid Secondary on Ion Mass Spectrometry) at $8 \mathrm{kV}$ with $\mathrm{Cs}^{+}$in $m$-nitrobenzyl alcohol (mNBA); $\mathrm{ES}^{+}$(electrospray ionization, positive mode) at $4 \mathrm{kV}$; El (electron ionization) at $70 \mathrm{eV}$. Elemental analyses were performed at C.R.M.P.O.

5-lodo-2-thiophenecarboxaldehyde (3). A mixture of 2 thiophenecarboxaldehyde $(1.79 \mathrm{~g}, 15.92 \mathrm{mmol})$, iodine $(2.00 \mathrm{~g}, 7.96$ $\mathrm{mmol})$ in carbon tetrachloride $(4 \mathrm{~mL})$, iodic acid $(0.70 \mathrm{~g}, 3.98 \mathrm{mmol})$, distilled water $(3 \mathrm{~mL})$, acetic acid $(8 \mathrm{~mL})$ and concentrated sulfuric acid $(0.12 \mathrm{~mL})$ were stirred under reflux for $1 \mathrm{~h}$ and at room temperature for another $12 \mathrm{~h}$. After washing with $2 \% \mathrm{NaHCO}_{3}$ and $\mathrm{Na}_{2} \mathrm{~S}_{2} \mathrm{O}_{3}$ the organic layer was dried over anhydrous $\mathrm{MgSO}_{4}$ and the solvent was removed in vacuum. The crude product was purified by column chromatography eluting with ethyl acetate/ heptane (1:9) to yield $2.95 \mathrm{~g}(78 \%)$ of $\mathbf{3}$ as yellowish crystals, mp $53{ }^{\circ} \mathrm{C} ;{ }^{1} \mathrm{H}$ NMR $\left(\mathrm{CDCl}_{3}\right): 9.8(\mathrm{~s}, 1 \mathrm{H}), 7.4(\mathrm{~s}, 2 \mathrm{H})$. ${ }^{13} \mathrm{C} \mathrm{NMR}\left(\mathrm{CDCl}_{3}\right): 181.1,149.6,138.2,137.0,87.8$.

2-(Ethyl-[4-[2-(5-iodothiophen-2-yl)vinyl]phenyl]amino)ethanol (7a) Air was removed from a mixture of $3(1.95 \mathrm{~g}, 8.19 \mathrm{mmol})$, phosphonium salt $6(6.32 \mathrm{~g}, 12.29 \mathrm{mmol})$ and tBuOK $(1.84 \mathrm{~g}, 16.38 \mathrm{mmol})$ by bubbling with argon for $20 \mathrm{~min}$. Fresh distilled $\mathrm{CH}_{2} \mathrm{Cl}_{2}(50 \mathrm{~mL})$ was added. The solution was stirred at room temperature for $16 \mathrm{~h}$. It was then filtered through a short pad of silica gel. The solvent was removed under reduced pressure, and the crude product was purified by column chromatography eluting with $\mathrm{CH}_{2} \mathrm{Cl}_{2} /$ AcOEt (98:2 to $92: 8$ ) to yield $2.16 \mathrm{~g}$ of a mixture of $Z / E$ stereoisomers. To $1.34 \mathrm{~g}$ of this mixture of isomers dissolved in $\mathrm{Et}_{2} \mathrm{O}(50 \mathrm{~mL})$ was added a solution of iodine in $\mathrm{Et}_{2} \mathrm{O}\left(1 \mathrm{~g} \cdot \mathrm{L}^{-1}\right.$, $3.4 \mathrm{~mL}$ ). The mixture was then stirred $21 \mathrm{~h}$ at room temperature under light. After washing with sat $\mathrm{Na}_{2} \mathrm{~S}_{2} \mathrm{O}_{3}$, the organic layer was dried over anhydrous $\mathrm{MgSO}_{4}$ and the solvent was removed in vacuum to yield 1.02 g $(50 \%)$ of 7 a as yellow crystals. M.p: $93{ }^{\circ} \mathrm{C} .{ }^{1} \mathrm{H}$ NMR $\left(\mathrm{CDCl}_{3}\right): 7.3(\mathrm{~d}, \mathrm{~J}=$ $8.8 \mathrm{~Hz}, 2 \mathrm{H}), 7.1(\mathrm{~d}, \mathrm{~J}=3.7 \mathrm{~Hz}, 1 \mathrm{H}), 6.9(\mathrm{~d}, \mathrm{~J}=16 \mathrm{~Hz}, 1 \mathrm{H}), 6.78(\mathrm{~d}, \mathrm{~J}=16$ $\mathrm{Hz}, 1 \mathrm{H}), 6.74(\mathrm{~d}, \mathrm{~J}=8.8 \mathrm{~Hz}, 2 \mathrm{H}), 6.6(\mathrm{~d}, \mathrm{~J}=3.7 \mathrm{~Hz}, 1 \mathrm{H}), 3.8(\mathrm{q}, 2 \mathrm{H}), 3.5(\mathrm{~m}$, $4 \mathrm{H}), 1.6(\mathrm{t}, \mathrm{J}=5.8 \mathrm{~Hz}, 1 \mathrm{H}), 1.2(\mathrm{t}, \mathrm{J}=7 \mathrm{~Hz}, 3 \mathrm{H}) .{ }^{13} \mathrm{C} \mathrm{NMR}\left(\mathrm{CDCl}_{3}\right): 149.7$ $147.7,137.2,129.1,127.5,125.6,124.7,116.5,112.3,70.2,60.0,52.2$, $45.4,11.8$.

4-[2-(Ethyl-[4-[2-(5-iodothiophen-2-yl)vinyl]phenyl]amino)ethoxy]benzaldehyde $(7 \mathrm{~b})$. Under argon, a mixture of $7 \mathrm{a}(0.5 \mathrm{~g}, 1.25 \mathrm{mmol})$, 4hydroxybenzaldehyde $(0.31 \mathrm{~g}, 2.51 \mathrm{mmol})$ and triphenylphosphine $(0.66$ $\mathrm{g}, 2.51 \mathrm{mmol}$ ) was dissolved in THF $(15 \mathrm{~mL})$ and bubbled with argon for $20 \mathrm{~min}$. A solution of DIAD $(0.5 \mathrm{~mL}, 2.51 \mathrm{mmol})$ in THF $(3 \mathrm{~mL})$ was then added dropwise and the mixture was stirred overnight at room temperature. The solvent was removed in reduce pressure and the crude product was purified on column chromatography with $\mathrm{CH}_{2} \mathrm{Cl}_{2}$ to yield 0.51 
g $(81 \%)$ of yellow crystals. M.p: $108{ }^{\circ} \mathrm{C} .{ }^{1} \mathrm{H} \mathrm{NMR}\left(\mathrm{CDCl}_{3}\right) 9.9(\mathrm{~s}, 1 \mathrm{H}), 7.8$ $(\mathrm{d}, \mathrm{J}=8.8 \mathrm{~Hz}, 2 \mathrm{H}), 7.3(\mathrm{~d}, \mathrm{~J}=8.8 \mathrm{~Hz}, 2 \mathrm{H}), 7.1(\mathrm{~d}, \mathrm{~J}=3.7 \mathrm{~Hz}, 1 \mathrm{H}), 7.0(\mathrm{~d}$ $\mathrm{J}=8.7,2 \mathrm{H}), 6.9(\mathrm{~d}, \mathrm{~J}=15,5 \mathrm{~Hz}, 1 \mathrm{H}), 6.78(\mathrm{~d}, \mathrm{~J}=16 \mathrm{~Hz}, 1 \mathrm{H}), 6.72(\mathrm{~d}, \mathrm{~J}=$ $8.9 \mathrm{~Hz}, 2 \mathrm{H}), 6.65(\mathrm{~d}, \mathrm{~J}=3.7 \mathrm{~Hz}, 1 \mathrm{H}), 4.2(\mathrm{t}, \mathrm{J}=6 \mathrm{~Hz}, 2 \mathrm{H}), 3.8(\mathrm{t}, \mathrm{J}=5.9 \mathrm{~Hz}$ $2 \mathrm{H}$ ), 3.5 (q, $2 \mathrm{H}), 1.3$ (t, J= $7 \mathrm{~Hz}, 3 \mathrm{H}) .{ }^{13} \mathrm{C} \mathrm{NMR}\left(\mathrm{CDCl}_{3}\right)$ : 190.7, 163.6, $147.2,145.6,133.4,131.9,130.19,130.16,129.5,127.9,124.3,120.2$, $117.1,114.7,111.9,99.4,98.2,65.8,49.5,45.8,12.3$.

\section{4-[2-(Ethyl-[4-[2-(5-trimethylsilanylethynylthiophen-2-yl)vinyl]} phenyl]amino)ethoxy]benzaldehyde (8): Air was removed from the solution of $7 \mathbf{b}(0.77 \mathrm{~g}, 1.54 \mathrm{mmol})$ dissolved in toluene $(15 \mathrm{~mL})$ and $\mathrm{Et}_{3} \mathrm{~N}$ $(3 \mathrm{~mL})$ by bubbling with argon for $20 \mathrm{~min}$. After heating at $40{ }^{\circ} \mathrm{C}$, Cul $(6$ $\mathrm{mg}, \quad 0.03 \mathrm{mmol}), \quad \mathrm{Pd}\left(\mathrm{PPh}_{3}\right)_{2} \mathrm{Cl}_{2} \quad(22 \mathrm{mg}, \quad 0.03 \mathrm{mmol})$ and ethynyltrimethylsilane $(0.33 \mathrm{~mL}, 2.31 \mathrm{mmol})$ were added. The mixture was stirred at $40{ }^{\circ} \mathrm{C}$ overnight. Solvent was removed by reduce pressure and the crude product was purified by column chromatography with $\mathrm{CH}_{2} \mathrm{Cl}_{2} /$ Heptane (6:4 to $7: 3$ ) to yield $0.63 \mathrm{~g}(87 \%)$ of $8 .{ }^{1} \mathrm{H} \mathrm{NMR}\left(\mathrm{CDCl}_{3}\right)$ : $9.9(\mathrm{~s}, 1 \mathrm{H}), 7.9(\mathrm{~d}, \mathrm{~J}=9 \mathrm{~Hz}, 2 \mathrm{H}), 7.4(\mathrm{~d}, \mathrm{~J}=9 \mathrm{~Hz}, 2 \mathrm{H}), 7.1$ (d, J=3.7 Hz, $1 \mathrm{H}), 7.01(\mathrm{~d}, \mathrm{~J}=8.7 \mathrm{~Hz}, 2 \mathrm{H}), 6.97(\mathrm{~d}, \mathrm{~J}=16 \mathrm{~Hz}, 1 \mathrm{H}), 6.85(\mathrm{~d}, \mathrm{~J}=16 \mathrm{~Hz}$, $1 \mathrm{H}), 6.82(\mathrm{~d}, \mathrm{~J}=3.8 \mathrm{~Hz}, 1 \mathrm{H}), 6.7(\mathrm{~d}, \mathrm{~J}=8.9 \mathrm{~Hz}, 2 \mathrm{H}), 4.2(\mathrm{t}, \mathrm{J}=6 \mathrm{~Hz}, 2 \mathrm{H})$, $3.8(\mathrm{t}, \mathrm{J}=5.9 \mathrm{~Hz}, 2 \mathrm{H}), 3.5(\mathrm{q}, 2 \mathrm{H}), 1.3(\mathrm{t}, \mathrm{J}=7 \mathrm{~Hz}, 3 \mathrm{H}), 0.3(\mathrm{~s}, 9 \mathrm{H}) .{ }^{13} \mathrm{C}$ $\mathrm{NMR}\left(\mathrm{CDCl}_{3}\right): 190.7,163.6,147.2,145.6,133.4,131.9,130.19,130.16$, $129.5,127.9,124.3,120.2,117.1,114.7,111.9,99.4,98.2,65.8,49.5$, $45.8,12.3$. 4-[2-(Ethylphenyl-mino)ethoxy]phenol (2a):
(phenyl)amino]ethanol (1) $(3.00 \mathrm{~g}, 18.07 \mathrm{mmol})$, hydroquinone $(3.98 \mathrm{~g}$,
$36.14 \mathrm{mmol})$ and $\mathrm{PPh}_{3}(9.51 \mathrm{~g}, 36.14 \mathrm{mmol})$ were dissolved in THF $(55$
$\mathrm{mL})$. Air was removed by bubbling with argon for 20 min. A solution of
DIAD (7.16 mL, $36.14 \mathrm{mmol})$ in THF $(35 \mathrm{~mL})$ was then added dropwise
and the mixture was stirred overnight at room temperature. The solvent
was removed in reduce pressure and the crude product was purified on
column chromatography with $\mathrm{CH}_{2} \mathrm{Cl}_{2}$ to yield $1.68 \mathrm{~g}(36 \%) .{ }^{1} \mathrm{H} \mathrm{NMR}$
$\left(\mathrm{CDCl}_{3}\right): 7.38(\mathrm{q}, 2 \mathrm{H}), 6.87(\mathrm{~m}, 7 \mathrm{H}), 6.58(\mathrm{~s}, 1 \mathrm{H}), 4.17(\mathrm{t}, \mathrm{J}=6.3 \mathrm{~Hz}, 2 \mathrm{H})$,
$3.80(\mathrm{t}, \mathrm{J}=6.3 \mathrm{~Hz}, 2 \mathrm{H}), 3.59(\mathrm{q}, 2 \mathrm{H}), 1.31(\mathrm{t}, \mathrm{J}=6.9 \mathrm{~Hz}, 3 \mathrm{H}) .{ }^{13} \mathrm{C} \mathrm{NMR}$
$\left.(\mathrm{CDCl})_{3}\right): 152.6,149.6,147.4,129.3,116.1,115.5,111.9,66.0,49.6,45.5$, 12.1 .

\section{[[4-[Ethyl[2-(4-hydroxyphenoxy)ethyl]amino]phenyl]methyl]-}

triphenylphosphonium iodide (2b): Compound $7(0.600 \mathrm{~g}, 2.34 \mathrm{mmol})$, $\mathrm{PPh}_{3}(0.552 \mathrm{~g}, 2.34 \mathrm{mmol})$ and paraformaldehyde $(0.063 \mathrm{~g}, 0.70 \mathrm{mmol})$ were dissolved in toluene $(8 \mathrm{~mL})$. Nal $(0.434 \mathrm{~g}, 2.34 \mathrm{mmol})$, water $(0.4$ $\mathrm{mL}$ ) and acetic acid $(1.2 \mathrm{~mL})$ were then added. The solution was stirred for $66 \mathrm{~h}$ at $61^{\circ} \mathrm{C}$. Water $(30 \mathrm{~mL})$ was added and the mixture was stirred for $10 \mathrm{~min}$. The aqueous layer was extracted with $\mathrm{CH}_{2} \mathrm{Cl}_{2}$ and the combined organic layers were washed with $\mathrm{NaHCO}_{3}(20 \mathrm{~mL})$ and water $(20 \mathrm{~mL})$, dried and evaporated under reduced pressure. The crude product was washed with $\mathrm{Et}_{2} \mathrm{O}$ to afford $1.362 \mathrm{~g}$ of $\mathbf{2 b}(88 \%) .{ }^{1} \mathrm{H}$ NMR $\left(\mathrm{CDCl}_{3}\right)$ : $7.64(\mathrm{~m}, 15 \mathrm{H}), 7.05(\mathrm{~d}, \mathrm{~J}=8.7 \mathrm{~Hz}, 2 \mathrm{H}), 6.76(\mathrm{~m}, 4 \mathrm{H}), 6.44(\mathrm{~d}$, $\mathrm{J}=8.7 \mathrm{~Hz}, 2 \mathrm{H}), 4.88(\mathrm{~d}, \mathrm{~J}=12.9 \mathrm{~Hz}, 2 \mathrm{H}), 4.05(\mathrm{t}, \mathrm{J}=6.3 \mathrm{~Hz}, 2 \mathrm{H}), 3.77$ (s,1H), $3.71(\mathrm{t}, \mathrm{J}=6.3 \mathrm{~Hz}, 2 \mathrm{H}), 3.48(\mathrm{q}, 2 \mathrm{H}), 1.22(\mathrm{t}, \mathrm{J}=6.9 \mathrm{~Hz}, 3 \mathrm{H}) .{ }^{13} \mathrm{C}$ NMR (DMSO- $\left.\mathrm{d}_{6}\right):$ 151.2, 151.0, $147.2(\mathrm{~d}, \mathrm{~J}=2.7 \mathrm{~Hz}), 134.8(\mathrm{~d}, \mathrm{~J}=2.9$ $\mathrm{Hz}), 133.9(\mathrm{~d}, \mathrm{~J}=9.7 \mathrm{~Hz}), 131.0(\mathrm{~d}, \mathrm{~J}=9.7 \mathrm{~Hz}), 129.9(\mathrm{~d}, \mathrm{~J}=12.2 \mathrm{~Hz})$, $118.1(\mathrm{~d}, \mathrm{~J}=84.7 \mathrm{~Hz}), 115.6,115.2,112.4(\mathrm{~d}, \mathrm{~J}=8.7 \mathrm{~Hz}), 111.5,65.7$, 48.8, 44.5, 27.5 (d, J = 45.0 Hz), 11.6. ${ }^{31} \mathrm{P}$ NMR (DMSO-d $)$ : 21.1 .

\section{4-[2-(Ethyl-[4-[2-(5-iodothiophen-2-yl)vinyl]phenyl]amino)ethoxy]-} phenol (4a): Air was removed from a mixture of $\mathbf{2 b}(2.09 \mathrm{~g}, 3.18 \mathrm{mmol})$, $3(0.556 \mathrm{~g}, 2.34 \mathrm{mmol})$ and tBuOK $(0.53 \mathrm{~g}, 4.67 \mathrm{mmol})$ by bubbling with argon for $20 \mathrm{~min}$. Fresh distilled $\mathrm{CH}_{2} \mathrm{Cl}_{2}(25 \mathrm{~mL})$ was added. The solution was stirred at room temperature overnight, then filtered through a short pad of mixed celite and silica gel. The solvent was removed under reduce pressure, and the crude product was purified on column chromatography with mixed solvent $\mathrm{CH}_{2} \mathrm{Cl}_{2}$ to yield $0.62 \mathrm{~g}$ of $\mathrm{Z} / \mathrm{E}$ stereoisomers (45/55). The mixture of isomers was then mixed with $I_{2}$ in $\mathrm{Et}_{2} \mathrm{O}$ under beam of light to obtain 4a (54\%). M.p: $114{ }^{\circ} \mathrm{C}$. ${ }^{1} \mathrm{H}$ NMR $\left(\mathrm{CDCl}_{3}\right): 7.34(\mathrm{~d}, \mathrm{~J}=8.8 \mathrm{~Hz}, 2 \mathrm{H}), 7.11(\mathrm{~d}, \mathrm{~J}=3.8 \mathrm{~Hz}, 1 \mathrm{H}), 6.98(\mathrm{~d}, \mathrm{~J}=16$ $\mathrm{Hz}, 1 \mathrm{H}), 6.78(\mathrm{~d}, \mathrm{~J}=16 \mathrm{~Hz}, 1 \mathrm{H}), 6.77(\mathrm{~d}, \mathrm{~J}=2.5 \mathrm{~Hz}, 4 \mathrm{H}), 6.71(\mathrm{~d}, \mathrm{~J}=9 \mathrm{~Hz}$ $2 \mathrm{H}), 6.64(\mathrm{~d}, \mathrm{~J}=3.8 \mathrm{~Hz}, 1 \mathrm{H}), 4.53(\mathrm{~s}, 1 \mathrm{H}), 4.09(\mathrm{t}, \mathrm{J}=6.3 \mathrm{~Hz}, 2 \mathrm{H}), 3.74(\mathrm{t}$, $\mathrm{J}=6 \mathrm{~Hz}, 2 \mathrm{H}) 3.53(\mathrm{q}, 2 \mathrm{H}), 1.24(\mathrm{t}, \mathrm{J}=6.9 \mathrm{~Hz}, 3 \mathrm{H}) .{ }^{13} \mathrm{C} \mathrm{NMR}\left(\mathrm{CDCl}_{3}\right): 152.7$, $149.9,149.7,147.4,137.4,129.4,127.8,125.8,124.4,116.5,116.1$, $115.5,111.8,70.3,66.0,49.6,45.6,12.3$

Acetic acid 4-[2-(ethyl-[4-[2-(5-iodothiophen-2-yl)vinyl]phenyl]amino)ethoxy]phenyl ester (4b): Under argon, to a mixture of $4 a(0.62$ $\mathrm{g}, 1.26 \mathrm{mmol}$ ) in $\mathrm{CH}_{2} \mathrm{Cl}_{2}(36 \mathrm{~mL})$, DMAP $(22 \mathrm{mg}, 0.18 \mathrm{mmol}$ ) was added and stirred $5 \mathrm{~min}$ at $0^{\circ} \mathrm{C}$. At $0^{\circ} \mathrm{C}, \mathrm{Et}_{3} \mathrm{~N}(0.39 \mathrm{~mL})$ was then added and acetyl chloride $(0.19 \mathrm{~mL}, 2.73 \mathrm{mmol})$ was added dropwise. The mixture was stirred overnight at room temperature. Ice was added in solution followed by $\mathrm{NaHCO}_{3 \text { sat }}(20 \mathrm{~mL}$ ) and stirred $5 \mathrm{~min}$. The organic layer was then extracted $(3 \times 15 \mathrm{~mL})$, dried and concentrated under vacuum. The crude product was purified on column chromatography with $\mathrm{CH}_{2} \mathrm{Cl}_{2}$ to yield $0.61 \mathrm{~g}(97 \%)$ of $\mathbf{4 b}$. ${ }^{1} \mathrm{H}$ NMR $\left(\mathrm{CDCl}_{3}\right): 7.34(\mathrm{~d}, \mathrm{~J}=8.7 \mathrm{~Hz}, 2 \mathrm{H}), 7.11$ (d, $3.7 \mathrm{~Hz} \mathrm{1H}), 7.01(\mathrm{~d}, 9 \mathrm{~Hz}, 2 \mathrm{H}), 6.98(\mathrm{~d}, \mathrm{~J}=16 \mathrm{~Hz}, 1 \mathrm{H}), 6.89(\mathrm{~d}, \mathrm{~J}=9.3$ $\mathrm{Hz}, 2 \mathrm{H}), 6.78(\mathrm{~d}, \mathrm{~J}=16 \mathrm{~Hz}, 1 \mathrm{H}), 6.71(\mathrm{~d}, \mathrm{~J}=9 \mathrm{~Hz}, 2 \mathrm{H}), 6.64(\mathrm{~d}, \mathrm{~J}=4 \mathrm{~Hz}$ 1H). ${ }^{13} \mathrm{C}$ NMR $\left(\mathrm{CDCl}_{3}\right): 169.8,156.3,150.0,147.3,144.4,137.4,129.5$ $127.8,125.8,124.6,122.4,116.6,115.0,111.82,111.8,70.3,65.8,49.6$ $45.7,12.3$.

Acetic acid 4-[2-(ethyl-[4-[2-(5-trimethylsilanylethynylthiophen-2yl)vinyl]phenyl]amino)ethoxy]phenyl ester (5): Air was removed from the solution of $4 \mathbf{b}(0.37 \mathrm{~g}, 0.70 \mathrm{mmol})$ dissolved in toluene $(5 \mathrm{~mL})$ and $\mathrm{Et}_{3} \mathrm{~N}(1 \mathrm{~mL})$ by bubbling with argon for $20 \mathrm{~min}$. After heating at $40^{\circ} \mathrm{C}$, Cul (3 $\mathrm{mg}, \quad 0.02 \mathrm{mmol}), \quad \mathrm{Pd}\left(\mathrm{PPh}_{3}\right)_{2} \mathrm{Cl}_{2} \quad(12 \mathrm{mg}, 0.02 \mathrm{mmol})$ and ethynyltrimethylsilane $(0.19 \mathrm{~mL}, 1.31 \mathrm{mmol})$ were added. The mixture was stirred at $40{ }^{\circ} \mathrm{C}$ overnight. Solvent was removed by reduce pressure and the crude product was purified by column chromatography with $\mathrm{CH}_{2} \mathrm{Cl}_{2} /$ Heptane $(6: 4)$ to yield $0.33 \mathrm{~g}(94 \%)$ of 5 . ${ }^{1} \mathrm{H} \mathrm{NMR}\left(\mathrm{CDCl}_{3}\right): 7.37$ (d, J= $9 \mathrm{~Hz}, 2 \mathrm{H}), 7.12(\mathrm{~d}, \mathrm{~J}=3.9 \mathrm{~Hz}, 1 \mathrm{H}), 7.03(\mathrm{~d}, \mathrm{~J}=9 \mathrm{~Hz}, 2 \mathrm{H}), 6.98$ (d, $\mathrm{J}=16 \mathrm{~Hz}, 1 \mathrm{H}), 6.90(\mathrm{~d}, \mathrm{~J}=9 \mathrm{~Hz}, 2 \mathrm{H}), 6.87(\mathrm{~d}, \mathrm{~J}=16 \mathrm{~Hz}, 1 \mathrm{H}), 6.83(\mathrm{~d}, \mathrm{~J}=$ $3.9 \mathrm{~Hz}, 1 \mathrm{H}), 6.72(\mathrm{~d}, \mathrm{~J}=9 \mathrm{~Hz}, 2 \mathrm{H}), 4.13(\mathrm{t}, \mathrm{J}=6 \mathrm{~Hz}, 2 \mathrm{H}), 3.77$ (t, J= 5.9 $\mathrm{Hz}, 2 \mathrm{H}), 3.54$ (q, 2H), 2.29 (s, 3H), $1.26(\mathrm{t}, \mathrm{J}=6.9 \mathrm{~Hz}, 3 \mathrm{H}), 0.30$ (s, $9 \mathrm{~Hz}$ ) ${ }^{13} \mathrm{C}$ NMR $\left(\mathrm{CDCl}_{3}\right): 169.7,156.11,156.09,147.2,145.5,144.14,144.11$ 142.2, 133.2, 132.2, 130.6, 129.9, 129.5, 127.7, 127.2, 124.0, 122.17 $122.15,119.9,119.7,116.7,114.8,111.6,111.2,99.1,98.0,65.6,49.42$ $49.39,45.5,45.4,31.7,31.28,31.22,29.97,29.91,29.48,29.45,29.41$ $29.29,29.15,28.9,28.7,22.5,20.8,13.9,12.1$.

\section{4-[2-[[4-[(1E)-2-[5-[(9,9-dibutyl-7-iodo-9H-fluoren-2-yl)ethynyl]2-} thienyl] ethenyl]phenyl]ethylamino]ethoxy]benzaldehyde (9a): Air was removed from a mixture of $8(0.63 \mathrm{~g}, 1.34 \mathrm{mmol}), 9,9$-dibutyl-2,7diiodo-9H-fluorene $9(2.13 \mathrm{~g}, 4.01 \mathrm{mmol})$ and $\mathrm{Et}_{3} \mathrm{~N}(2.4 \mathrm{~mL})$ dissolved in toluene $\left(12 \mathrm{~mL}\right.$ ) by bubbling with argon for $20 \mathrm{~min}$. After heating at $40^{\circ} \mathrm{C}$, Cul $(5.7 \mathrm{mg}, 0.03 \mathrm{mmol})$ and $\mathrm{Pd}\left(\mathrm{PPh}_{3}\right)_{2} \mathrm{Cl}_{2}(21 \mathrm{mg}, 0.03 \mathrm{mmol})$ were added. Air was removed from the solution of TBAF in THF $(1 \mathrm{M}, 0.80$ $\mathrm{mmol}$ ) by blowing argon for $5 \mathrm{~min}$ and then added to the mixture. The solution was stirred overnight at $40^{\circ} \mathrm{C}$. Solvent was removed by reduce pressure and the crude product was purified by column chromatography with mixed solvent $\mathrm{CH}_{2} \mathrm{Cl}_{2} / \mathrm{Heptane}(6: 4)$ to yield $0.83 \mathrm{~g}(77 \%)$ of orange crystals of compound 9a. M.p: $146{ }^{\circ} \mathrm{C} .{ }^{1} \mathrm{H}$ NMR $\left(\mathrm{CDCl}_{3}\right): 9.89(\mathrm{~s}, 1 \mathrm{H})$ $7.85(\mathrm{~d}, \mathrm{~J}=8.9 \mathrm{~Hz}, 2 \mathrm{H}), 7.68(\mathrm{dd}, \mathrm{J}=1.6 \mathrm{~Hz}, 1 \mathrm{H}), 7.66(\mathrm{~s}, 1 \mathrm{H}), 7.63(\mathrm{~d}, \mathrm{~J}=$ $8.6 \mathrm{~Hz}, 1 \mathrm{H}), 7.51(\mathrm{dd}, \mathrm{J}=1.4 \mathrm{~Hz}, 1 \mathrm{H}), 7.46(\mathrm{~s}, 1 \mathrm{H}), 7.42(\mathrm{~d}, \mathrm{~J}=8.4 \mathrm{~Hz}$ $1 \mathrm{H}), 7.39(\mathrm{~d}, \mathrm{~J}=9 \mathrm{~Hz}, 2 \mathrm{H}), 7.18(\mathrm{~d}, \mathrm{~J}=3.6 \mathrm{~Hz}, 1 \mathrm{H}), 7.01(\mathrm{~d}, \mathrm{~J}=8.7 \mathrm{~Hz}$ 2H), $6.96(d, J=16 \mathrm{~Hz}, 1 \mathrm{H}), 6.90(\mathrm{~d}, \mathrm{~J}=3.3 \mathrm{~Hz}, 1 \mathrm{H}), 6.89(\mathrm{~d}, \mathrm{~J}=15.3 \mathrm{~Hz}$ $1 \mathrm{H}), 6.73(\mathrm{~d}, \mathrm{~J}=9 \mathrm{~Hz}, 2 \mathrm{H}), 4.25(\mathrm{t}, \mathrm{J}=6.3 \mathrm{~Hz}, 2 \mathrm{H}), 3.83(\mathrm{t}, \mathrm{J}=5.7 \mathrm{~Hz}, 2 \mathrm{H})$, $3.56(\mathrm{q}, 2 \mathrm{H}), 1.96(\mathrm{~m}, 4 \mathrm{H}), 1.26(\mathrm{t}, \mathrm{J}=7.2 \mathrm{~Hz}, 3 \mathrm{H}), 1.14(\mathrm{q}, 4 \mathrm{H}), 0.72(\mathrm{t}$ $\mathrm{J}=7.2 \mathrm{~Hz}, 6 \mathrm{H}), 0.56(\mathrm{~m}, 4 \mathrm{H}) .{ }^{13} \mathrm{C} \mathrm{NMR}\left(\mathrm{CDCl}_{3}\right): 190.6,163.4,153.2$, $150.0,147.0,145.5,140.2,139.8,135.8,132.5,131.87,131.82,130.3$ 
$129.9,129.3,127.8,125.4,124.7,124.6,121.7,121.5,120.2,119.6$ $116.9,114.5,111.7,94.6,92.9,83.7,65.6,55.1,49.3,45.6,39.9,29.5$, 25.7, 22.8, 13.6, 12.2. HRMS (ESI) calcd for $\mathrm{C}_{46} \mathrm{H}_{46} \mathrm{NO}_{2} \mathrm{INaS}\left[(\mathrm{M}+\mathrm{Na})^{+}\right]$ $\mathrm{m} / \mathrm{z}$ 826.21862, found 826.2185.

\section{4-[2-[[4-[(1E)-2-[5-[2-[9,9-dibutyl-7-[2-[5-[(1E)-2-[4-[ethyl-[2-[4-} (formyl)phenoxy]ethyl]amino]phenyl]ethenyl]-2-thienyl]ethynyl]- $9 \mathrm{H}$ fluoren-2-yl]ethynyl]-2-thienyl]ethenyl]phenyl]ethylamino]ethoxy]phenyl acetate (9b): Air was removed from $5(0.33 \mathrm{~g}, 0.66 \mathrm{mmol})$, the previous compound $9 \mathrm{a}(0.48 \mathrm{~g}, 0.60 \mathrm{mmol})$ and $\mathrm{Et}_{3} \mathrm{~N}(2.8 \mathrm{~mL})$ dissolved in toluene $(14 \mathrm{~mL})$ by bubbling with argon for $20 \mathrm{~min}$. After heating at $40^{\circ} \mathrm{C}$, Cul $(2.3 \mathrm{mg}, 12 \mu \mathrm{mol})$ and $\mathrm{Pd}\left(\mathrm{PPh}_{3}\right)_{2} \mathrm{Cl}_{2}(8.4 \mathrm{mg}, 12 \mu \mathrm{mol})$ were added. Air was removed from the solution of TBAF in THF ( $1 \mathrm{M}, 0.42$ $\mathrm{mmol}$ ) by blowing argon for $5 \mathrm{~min}$ and then added to the mixture. The solution was stirred overnight at $40{ }^{\circ} \mathrm{C}$. Solvent was removed by reduce pressure and the crude product was purified by column chromatography with mixed solvent $\mathrm{CH}_{2} \mathrm{Cl}_{2} /$ Heptane (7:3) to yield $0.46 \mathrm{~g}(70 \%)$ of orange crystals of compound 9b. M.p: $160{ }^{\circ} \mathrm{C}$. ${ }^{1} \mathrm{H}$ NMR $\left(\mathrm{CDCl}_{3}\right): 9.89(\mathrm{~s}, 1 \mathrm{H})$ $7.85(\mathrm{~d}, \mathrm{~J}=9 \mathrm{~Hz}, 2 \mathrm{H}), 7.68$ (d, J=8.6 Hz, 2H), $7.52(\mathrm{~m}, 4 \mathrm{H}), 7.39$ (dd, J=3 $\mathrm{Hz}, 4 \mathrm{H}), 7.19$ (d, J=4 Hz, 2H), 7.02 (d, J=16 Hz, 2H), 7.01 (d, J=9 Hz, $2 \mathrm{H}), 6.90(\mathrm{~s}, 4 \mathrm{H}), 6.89(\mathrm{~s}, 2 \mathrm{H}), 6.85(\mathrm{~d}, \mathrm{~J}=16 \mathrm{~Hz}, 2 \mathrm{H}), 6.74(\mathrm{dd}, \mathrm{J}=3 \mathrm{~Hz}$ $4 \mathrm{H}), 4.24$ (t, J=6 Hz, 2H), 4.14 (t, J=6 Hz, 2H), $3.82(\mathrm{~m}, 4 \mathrm{H}), 3.53$ (qd, $4 \mathrm{H}), 2.29(\mathrm{~s}, 3 \mathrm{H}), 2.03(\mathrm{~m}, 4 \mathrm{H}), 1.28(\mathrm{td}, \mathrm{J}=3.9 \mathrm{~Hz}, 6 \mathrm{H}), 1.16(\mathrm{~m}, 4 \mathrm{H})$, $0.73(\mathrm{t}, \mathrm{J}=7.2 \mathrm{~Hz}, 6 \mathrm{H}), 0.63(\mathrm{~m}, 4 \mathrm{H}) .{ }^{13} \mathrm{C} \mathrm{NMR}\left(\mathrm{CDCl}_{3}\right): 190.9,170.0$, $163.8,156.4,151.2,145.8,144.5,132.8,132.2,130.6,130.3,129.8$, $128.1,125.83,125.76,125.0,124.0,124.81,124.77,122.5,120.6,120.1$ 117.3, 115.2, 114.9, 111.9, 65.94, 65.92, 55.3, 49.8, 49.62, 49.60, 45.96, 45.86, 26.0, 23.2, 21.1, 13.9, 12.5. HRMS (ESI) calcd for $\mathrm{C}_{72} \mathrm{H}_{70} \mathrm{~N}_{2} \mathrm{O}_{5} \mathrm{NaS}_{2}\left[(\mathrm{M}+\mathrm{Na})^{+}\right] \mathrm{m} / \mathrm{z} 1129.46184$, found 1129.4620 .

Photosensitizer 10: The compound 9b (0.46 g, $0.42 \mathrm{mmol})$ was dissolved in a mixture of $\mathrm{EtOH}(10 \mathrm{~mL})$ and $\mathrm{THF}(28 \mathrm{~mL}) . \mathrm{NaOH}(4 \mathrm{~mL})$ was then added and the solution was stirred $20 \mathrm{~min}$ at room temperature, and $\mathrm{HCl}(15 \mathrm{~mL})$ was added. Aqueous layer was extracted with $\mathrm{CH}_{2} \mathrm{Cl}_{2}$ $(10 \mathrm{~mL})$, and organic layer was then washed with water $(5 \mathrm{~mL})$. The organic layer was dried and concentrated under vacuum. The crude product was purified on column chromatography with $\mathrm{CH}_{2} \mathrm{Cl}_{2}$ to yield 0.37 $\mathrm{g}(84 \%)$ of orange crystals of 10 . M.p: $94{ }^{\circ} \mathrm{C} .{ }^{1} \mathrm{H}$ NMR $\left(\mathrm{CDCl}_{3}\right): 9.89$ (s, $1 \mathrm{H}), 7.85(\mathrm{~d}, \mathrm{~J}=9 \mathrm{~Hz}, 2 \mathrm{H}), 7.68(\mathrm{~d}, \mathrm{~J}=8.6 \mathrm{~Hz}, 2 \mathrm{H}), 7.52(\mathrm{~m}, 4 \mathrm{H}), 7.39$ (dd, $\mathrm{J}=3 \mathrm{~Hz}, 4 \mathrm{H}), 7.19$ (d, J=4 Hz, 2H), 7.01 (d, J=9 Hz, 2H), 6.99 (2×d, J=16 $\mathrm{Hz}, 2 \mathrm{H}), 6.89(\mathrm{~m}, 2 \mathrm{H}), 6.87$ (d, J=16 Hz, 2H), 6.77 (s, 4H), 6.74 (dd, J=3 $\mathrm{Hz}, 4 \mathrm{H}), 5.19(\mathrm{~s}, 1 \mathrm{H}), 4.24(\mathrm{t}, \mathrm{J}=6 \mathrm{~Hz}, 2 \mathrm{H}), 4.10(\mathrm{t}, \mathrm{J}=6 \mathrm{~Hz}, 2 \mathrm{H}), 3.82$ (t, $\mathrm{J}=5.7 \mathrm{~Hz}, 2 \mathrm{H}), 3.73(\mathrm{t}, \mathrm{J}=5.7 \mathrm{~Hz}, 2 \mathrm{H}), 3.53(\mathrm{~m}, 4 \mathrm{H}), 2.01(\mathrm{~m}, 4 \mathrm{H}), 1.28$ $(2 \times t, J=3.9 \mathrm{~Hz}, 6 \mathrm{H}), 1.16(\mathrm{~m}, 4 \mathrm{H}), 0.73(\mathrm{t}, \mathrm{J}=7.2 \mathrm{~Hz}, 6 \mathrm{H}), 0.63(\mathrm{~m}, 4 \mathrm{H})$. ${ }^{13} \mathrm{C} \mathrm{NMR}\left(\mathrm{CDCl}_{3}\right): 191.1,163.8,152.8,151.2,149.9,147.6,147.3,145.9$, $145.8,140.76,140.71,132.77,132.16,130.6,130.1,129.8,129.6$, $128.04,128.01,125.7,124.93,124.86,124.7,124.6,121.83,121.77$, $120.5,120.3,120.1,117.2,116.9,116.1,115.6,114.8,111.9,111.8$, 105.0, 95.0, 84.07, 84.01, 66.1, 65.9, 55.3, 49.8, 49.5, 45.9, 45.7, 40.3, 25.9, 23.1, 13.9, 12.43, 12.40. HRMS (ESI) calcd for $\mathrm{C}_{70} \mathrm{H}_{69} \mathrm{~N}_{2} \mathrm{O}_{4} \mathrm{~S}_{2}$ $\left[(\mathrm{M}+\mathrm{H})^{+}\right] \mathrm{m} / \mathrm{z}$ 1065.46933, found 1065.4691. ATR-FTIR $\left(\mathrm{cm}^{-1}\right): 3363$, 2926, 2189, 2037, 1685, 1596, 1507, 1446, 1397, 1349, 1256, 1221, $1182,1158,1136,1074,1020,946,885,806,751$.

4-[2-[2-(2-Methoxyethoxy)ethoxy]ethoxy]phenol (12). In a solution of triethylene glycol monomethyl ether $(6.00 \mathrm{~g}, 36.58 \mathrm{mmol})$ in $\mathrm{CH}_{2} \mathrm{Cl}_{2}(10$ $\mathrm{mL}$ ) at $0^{\circ} \mathrm{C}$, was added $\mathrm{Et}_{3} \mathrm{~N}(5.83 \mathrm{~mL})$. The mixture was cooled below $5^{\circ} \mathrm{C}$. Stirring vigorously and maintaining the reaction mixture at that temperature, a solution of $p$-toluenesulfonyl chloride $(3.25 \mathrm{~mL} ; 42.07$ $\mathrm{mmol}$ ) in $3 \mathrm{~mL}$ of $\mathrm{CH}_{2} \mathrm{Cl}_{2}$ was added dropwise. Stirring was continued overnight at room temperature. A white precipitate was filtered and the filtrate was washed with $\mathrm{NaHCO}_{3}(2 \times 10 \mathrm{~mL})$. The aqueous layer was extracted with $\mathrm{CH}_{2} \mathrm{Cl}_{2}$. Organic layers were combined, dried over $\mathrm{Na}_{2} \mathrm{SO}_{4}$ then evaporated under reduce pressure to yield $8.46 \mathrm{~g}(95 \%)$ of yellow oil.
In a solution of this oil $(8.46 \mathrm{~g}, 34.97 \mathrm{mmol})$ in $25 \mathrm{~mL}$ of DMSO, was added hydroquinone $(3.86 \mathrm{~g}, 34.97 \mathrm{mmol})$, and $\mathrm{KOH}(5.89 \mathrm{~g}, 104.91$ $\mathrm{mmol}$ ). The mixture was stirred overnight at room temperature (wate bath) and $20 \mathrm{~mL}$ of water was then added. The solution was extracted ( 3 $\times 30 \mathrm{~mL}$ ) with $\mathrm{Et}_{2} \mathrm{O}$ to remove both unreacted tosylate and disubstituted byproduct. The solution was then acidified with concentrated $\mathrm{HCl}$ and extracted with $\mathrm{CHCl}_{3}(3 \times 20 \mathrm{~mL})$. The combined organic layers were washed with water until neutrality, dried over $\mathrm{Na}_{2} \mathrm{SO}_{4}$, and concentrated in vacuo to yield $3.69 \mathrm{~g}(41 \%)$ of brown oil of $12 .{ }^{1} \mathrm{H} \mathrm{NMR}\left(\mathrm{CDCl}_{3}\right): 6.82$ $(\mathrm{s}, 1 \mathrm{H}), 6.73(\mathrm{~d}, \mathrm{~J}=9 \mathrm{~Hz}, 2 \mathrm{H}), 6.69(\mathrm{~d}, \mathrm{~J}=9 \mathrm{~Hz}, 2 \mathrm{H}), 3.98(\mathrm{t}, \mathrm{J}=4.8 \mathrm{~Hz}$ $2 \mathrm{H}), 3.79(\mathrm{t}, \mathrm{J}=4.8 \mathrm{~Hz}, 2 \mathrm{H}), 3.70(\mathrm{~m}, 6 \mathrm{H}), 3.55(\mathrm{~m}, 2 \mathrm{H}), 3.34(\mathrm{~s}, 3 \mathrm{H}) .{ }^{13} \mathrm{C}$ NMR $\left(\mathrm{CDCl}_{3}\right): 152.3,150.1,115.9,115.5,71.7,70.5,70.4,70.3,69.7$ 67.8, 58.8. HRMS (ESI) calcd for $\mathrm{C}_{13} \mathrm{H}_{20} \mathrm{~N}_{2} \mathrm{O}_{5} \mathrm{Na}\left[(\mathrm{M}+\mathrm{Na})^{+}\right] \mathrm{m} / \mathrm{z}$ 279.12029, found 279.1203. ATR-FTIR $\left(\mathrm{cm}^{-1}\right)$ : 3333.3, 2873.0, 1508.4 1448.9, 1355.7, 1214.9, 1096.0, 1064.3, 824.4, 753.1.

Dendrimer $\mathbf{2}-\mathbf{G}_{1}$. The reaction was shielded from the light. To a solution of photosensitizer $10(152 \mathrm{mg}, 142.72 \mu \mathrm{mol})$ in distilled THF $(0.75 \mathrm{~mL})$ was added $\mathrm{Cs}_{2} \mathrm{CO}_{3}$ (93 mg, $285.43 \mu \mathrm{mol}$ ). The solution was stirred $2 \mathrm{~h}$ at $35^{\circ} \mathrm{C}$. A solution of dendrimers bearing $\mathrm{P}(\mathrm{S}) \mathrm{Cl}_{2} \mathbf{1}-\mathrm{G}_{\mathbf{1}}(20 \mathrm{mg}, 10.95 \mu \mathrm{mol})$ in $0.75 \mathrm{~mL}$ of distilled THF was then added and stirred 7 days at $35^{\circ} \mathrm{C}$ The reaction was monitored by ${ }^{31} \mathrm{P}$ using a $\mathrm{C}_{6} \mathrm{D}_{6}$ capillary. The resulting mixture was filtered and dendrimer was precipitated in pentane $(200 \mathrm{~mL})$ The orange precipitate was purified on column chromatography (pentane: THF: 1:1 until THF 100\%) and washed several times with AcOEt, to eliminate the excess of 10 , and dried under reduce pressure to yield $106 \mathrm{mg}(69 \%)$ of orange powder. $\mathrm{Mp}: 178^{\circ} \mathrm{C} .{ }^{1} \mathrm{H} \mathrm{NMR}\left(\mathrm{CD}_{2} \mathrm{Cl}_{2}\right) 9.86$ $(\mathrm{s}, 12 \mathrm{H}), 7.82(\mathrm{~d}, J=8.7 \mathrm{~Hz}, 24 \mathrm{H}), 7.67(\mathrm{dd}, J=7.8 \mathrm{~Hz}, 24 \mathrm{H}), 7.59(\mathrm{~m}$ $66 \mathrm{H}$ ), 7.36 (d, $J=9 \mathrm{~Hz}, 24 \mathrm{H}), 7.30$ (d, $J=8.4 \mathrm{~Hz}, 24 \mathrm{H}), 7.16$ (dd, $J=3.9$ $\mathrm{Hz}, 24 \mathrm{H}), 7.05(\mathrm{~m}, 132 \mathrm{H}), 6.73(\mathrm{~d}, J=8.7 \mathrm{~Hz}, 48 \mathrm{H}), 6.64(\mathrm{~d}, J=7.5 \mathrm{~Hz}$, $24 \mathrm{H}), 4.24$ (t, $J=6 \mathrm{~Hz}, 24 \mathrm{H}), 3.98(\mathrm{t}, J=6 \mathrm{~Hz}, 24 \mathrm{H}), 3.80$ (t, $J=6 \mathrm{~Hz}$, $24 \mathrm{H}), 3.62$ (s br, 24H), 3.54 (q, 24H), 3.40 (s br, $24 \mathrm{H}), 3.21$ (d, J=12 Hz, $18 \mathrm{H}), 2.00(\mathrm{~m}, 48 \mathrm{H}), 1.21-1,02(\mathrm{~m}, 120 \mathrm{H}), 0.77-0.48(\mathrm{~m}, 120 \mathrm{H}) .{ }^{13} \mathrm{C} N M R$ $\left(\mathrm{CD}_{2} \mathrm{Cl}_{2}\right)$ 191.42, 164.63, 157.13, 152.18, 148.45, 146.77, 145.22, 141.67, $133.73,132.72,131.31,131.16,130.59,128.82,126.64,125.77,123.22$ $122.68,122.25,121.19,121.00,117.70,115.97,115.65,112.84,95.75$ $84.76,84.67,66.95,61.16,56.14,55.08,54.72,54.36,50.39,46.68$ $41.03,34.00,31.01,26.92,23.99,14.93,14.57,13.01 .{ }^{31} \mathrm{P}\left(\mathrm{CDCl}_{3}\right)$ 64.40, 8.63. LC/MS: calcd avg mass for $\mathrm{C}_{888} \mathrm{H}_{852} \mathrm{~N}_{39} \mathrm{O}_{54} \mathrm{NaP}_{9} \mathrm{~S}_{30}$ $\left[(\mathrm{M}+\mathrm{Na})^{+}\right] \mathrm{m} / \mathrm{z} 14198.2$ found: 14197.1 .

Dendrimer $\mathbf{1}-\mathbf{G}_{\mathbf{2}}$. The reaction was shielded from the light. $\mathbf{2}-\mathbf{G}_{\mathbf{1}}(\mathbf{8 6 . 4} \mathrm{mg}$, $6.10 \mu \mathrm{mol})$ was cooled at $0^{\circ} \mathrm{C}$ and $11(508.3 \mu \mathrm{L}, 91.5 \mu \mathrm{mol})$ in solution in $\mathrm{CHCl}_{3}$ was added. The solution was stirred 5 days at room temperature (monitored by ${ }^{1} \mathrm{H}$ NMR). Dendrimer was precipitated in pentane $(200 \mathrm{~mL})$, to remove excess of $\mathbf{1 1}$, filtered under argon then dried under reduce pressure to yield $85 \mathrm{mg}$ (86\%) of orange powder. M.p: $184{ }^{\circ} \mathrm{C} .{ }^{1} \mathrm{H}$ NMR $\left(\mathrm{CDCl}_{3}\right) 7.68(\mathrm{~m}, 120 \mathrm{H}), 7.38(\mathrm{~d}, J=8.4 \mathrm{~Hz}, 24 \mathrm{H}), 7.31(\mathrm{~d}, J=8.4 \mathrm{~Hz}$, $24 \mathrm{H}), 7.16$ (dd, $J=3.7 \mathrm{~Hz}, 24 \mathrm{H}), 7.06-6.63(\mathrm{~m}, 192 \mathrm{H}), 4.19$ (t, $J=4.5$ $\mathrm{Hz}, 24 \mathrm{H}), 3.96$ (s br, 24H), 3.80 (s br, $24 \mathrm{H}), 3.62$ (s br, $24 \mathrm{H}), 3.53(\mathrm{~m}$, $84 \mathrm{H}), 3.19(\mathrm{~d}, J=9.6 \mathrm{~Hz}, 18 \mathrm{H}), 1.98(\mathrm{~m}, 48 \mathrm{H}), 1.15(\mathrm{~m}, 120 \mathrm{H}), 0.69(\mathrm{~m}$ ${ }^{120 \mathrm{H}) .}{ }^{13} \mathrm{C}$ NMR $\left(\mathrm{CDCl}_{3}\right): 160.31,156.04,151.50,151.11,147.34$, $145.72,144.23,141.71,140.65,135.75,132.68,130.52,129.56,128.95$ $128.23,127.95,127.19,125.59,125.50,124.72,124.58,122.29,121.73$, $121.37,120.41,120.33,120.02,117.08,116.95,115.03,114.75,111.84$ $94.92,83.94,65.75,65.56,55.17,49.58,45.76,45.63,40.18,34.21$, $33.07,31.75,30.31,25.90,23.05,21.18,13.85,12.34,12.31 .{ }^{31} \mathrm{P}$ $\left(\mathrm{CDCl}_{3}\right)$ 64.41, 63.30, 8.66.

Dendrimer $\mathbf{2}-\mathrm{G}_{\mathbf{2}}$. The reaction was shielded from the light. To a solution of $12(12 \mathrm{mg}, 46.50 \mu \mathrm{mol})$ in distilled THF $(2 \mathrm{~mL})$, was added $\mathrm{Cs}_{2} \mathrm{CO}_{3}(29$ $\mathrm{mg}, 89.28 \mu \mathrm{mol})$ and stirred overnight at room temperature. $1-\mathrm{G}_{2}(30.1$ $\mathrm{mg}, 1.86 \mu \mathrm{mol}$ ) in $1.5 \mathrm{~mL}$ of distilled THF was then added to the mixture and stirred 5 days at room temperature. (monitored by $\left.{ }^{31} \mathrm{P} N \mathrm{NM}\right)$. The 
solution was filtered, and dendrimer was precipitated in pentane (200 $\mathrm{mL}$ ). The resulting powder was washed with $\mathrm{Et}_{2} \mathrm{O}$ to removed excess of 12 then solubilized in THF and centrifuged to remove cesium traces. Dendrimer was again precipitated in pentane, filtered under argon, and dried under reduce pressure to yield $30 \mathrm{mg}(75 \%)$ of orange powder. M.p: $178{ }^{\circ} \mathrm{C} .{ }^{1} \mathrm{H}$ NMR $\left(\mathrm{CDCl}_{3}\right)$ 7.68-7.28 (m, 168H), 7.13-6.52 (m, 317H), 4.16-3.16 (m, 558H), $1.97(\mathrm{~m}, 48 \mathrm{H}), 1.11(\mathrm{~m}, 120 \mathrm{H}), 0.66(\mathrm{~m}, 120 \mathrm{H}) .{ }^{31} \mathrm{P}$ $\left(\mathrm{CDCl}_{3}\right)$ 64.59, 8.61

\section{Photophysical studies}

UV-Vis absorption and emission spectroscopy. All photophysical measurements have been performed with freshly-prepared solutions in air-equilibrated THF at room temperature (298 K). UV/Vis absorption spectra were recorded on a Jasco V-570 spectrophotometer. Steadystate and time-resolved fluorescence measurements were performed on dilute solutions (ca. $10^{-6} \mathrm{M}$ chromophore concentration, optical density < 0.1 ) contained in standard $1 \mathrm{~cm}$ quartz cuvettes using an Edinburgh Instruments (FLS920) spectrometer in photon-counting mode. Emission spectra were obtained, for each compound, under excitation at the wavelength of the absorption maximum. Fluorescence quantum yields were measured according to literature procedures using quinine bisulfate in $0.5 \mathrm{M} \mathrm{H}_{2} \mathrm{SO}_{4}$ as a standard (quantum yield $\Phi=0.546$ ). ${ }^{[38]}$ The lifetime values were obtained from the reconvolution fit analysis (Edinburgh F900 analysis software) of decay profiles obtained using the FLS920 instrument under excitation with a nitrogen-filled nanosecond flash-lamp. The quality of the fits was evidenced by the reduced $\chi^{2}$ value $\left(\chi^{2}<1.1\right)$.

Measurements of singlet oxygen quantum yield $\left(\Phi_{\Delta}\right)$. Measurements were performed on a Fluorolog-3 (Horiba Jobin Yvon), using a $450 \mathrm{~W}$ Xenon lamp. The emission at $1272 \mathrm{~nm}$ was detected using a liquid nitrogen-cooled Ge-detector model (EO-817L, North Coast Scientific Co). Singlet oxygen quantum yields $\Phi_{\Delta}$ were determined in dichloromethane solutions, using tetraphenylporphyrin (TPP) in dichloromethane as reference solution $\left(\Phi_{\Delta}[\mathrm{TPP}]=0.60\right)$ and were estimated from ${ }^{1} \mathrm{O}_{2}$ luminescence at $1272 \mathrm{~nm}$.

Two-photon absorption. Two-photon absorption cross sections $\left(\sigma_{2}\right)$ were obtained from the two-photon excited fluorescence (2PEF) cross sections $\left(\sigma_{2} \Phi\right)$ and the fluorescence emission quantum yield $(\Phi)$. 2PEF cross sections in toluene $\left(10^{-4} \mathrm{M}\right.$ chromophore concentration) were determined using a Ti-sapphire laser delivering 150 fs excitation pulses, according to the experimental protocol established by $\mathrm{Xu}$ and Webb. ${ }^{[39]}$ This experimental protocol allows avoiding contributions from excited-state absorption that are known to result in largely overestimated 2PA cross sections. Fluorescein in $0.01 \mathrm{M} \mathrm{NaOH}$, whose 2PEF cross-sections are well-known, ${ }^{[39]}$ served as the reference, taking into account the necessary corrections for the refractive index of the solvents. ${ }^{[40]}$ The quadratic dependence of the fluorescence intensity on the excitation intensity was verified for each data point, indicating that the measurements were carried out in intensity regimes in which saturation or photodegradation do not occur. More details about the experimenta setup have been previously published. ${ }^{[31]}$

Cellular imaging. One- and two-photon imaging have been performed on Montpellier RIO Imaging (MRI) platform. For cell culture, MCF-7 human breast cancer cells (ATCC) were routinely cultured in Dulbecco's Modified Eagle Medium F-12 Nutrient Mixture (Ham) supplemented with glutamax, $10 \%$ foetal bovine serum, and 1/100 antibiotics (penicillin/ streptomycin). Cells were allowed to grow in humidified atmosphere at $37^{\circ} \mathrm{C}$ under $5 \% \mathrm{CO}_{2}$. On the one hand, cells were incubated $24 \mathrm{~h}$ with dendrimer $\mathbf{2}-\mathbf{G}_{2}\left(50 \mu \mathrm{g} \cdot \mathrm{mL}^{-1}\right)$. Thirty minutes before the end of incubation, cells were loaded with $2 \mu \mathrm{g} \cdot \mathrm{mL}^{-1}$ Hoechst 33342 for nuclear staining. After 30 min cells were washed and maintain in fresh culture medium without serum and phenol red. For confocal imaging, a Zeiss LSM 780 microscope equipped with DIC plan-apochromat $63 x / 1.4$ NA oil immersion objective was used. Nuclear staining was excited at $405 \mathrm{~nm}$ and $\mathbf{2}-\mathrm{G}_{2}$ at $548 \mathrm{~nm}$. On the other hand, cells were incubated $3 \mathrm{~h}$ with dendrimer $\mathbf{2}-\mathbf{G}_{2}(50 \mu \mathrm{g} / \mathrm{ml})$. Thirty minutes before the end of incubation, cells were loaded with $1 \mathrm{mg} \cdot \mathrm{mL}^{-1}$ CellMask for plasma membrane stains For multi-photon imaging, a Zeiss LSM 780 microscope with tuneable Chameleon Ultra II laser (Coherent, mode- locked Ti: sapphire laser $680-1080 \mathrm{~nm}$ ) and equipped with DIC plan-apochromat $63 \mathrm{x} / 1.4 \mathrm{NA}$ oil immersion objective was used. $\mathbf{2}-\mathbf{G}_{\mathbf{2}}$ and plasma membrane stains were excited at $750 \mathrm{~nm}$.

Two-photon excited photodynamic therapy. For experiments of 2PE PDT, MCF-7 breast cancer cells were seeded in a 384 multi-well plate with $0.17 \mathrm{~mm}$ glass bottom and incubated with or without $\mathbf{2}-\mathbf{G}_{2}(50 \mu \mathrm{g}$. $\mathrm{mL}^{-1}$ ) for 20 hours. After incubation, cells were washed, maintained in fresh culture medium and then submitted or not to laser irradiation. Two photon irradiation was carried out on MRI platform. PDT was then performed on a multi-photon confocal microscope Zeiss LSM 780 equipped with tuneable Chameleon Ultra II laser (Coherent, 680-1080 $\mathrm{nm}$ ) generating $140 \mathrm{fs}$ wide pulses at $80 \mathrm{MHz}$ rate. The laser beam was focused by a microscope objective lens (10x, NA 0.4). The wells were irradiated at $760 \mathrm{~nm}$ by 3 scans of $1.57 \mathrm{sec}$ each at an average power of $80 \mathrm{~mW}$. The surface of the scanned areas was $1.5 \times 1.5 \mathrm{~mm}^{2}$ (mean energy of $16.6 \mathrm{~J} \mathrm{~cm}^{-2}$ ). Two days after irradiation, the percentage of living cells was determined by MTS (3-(4,5-dimethylthiazol-2-yl)-5-(3 carboxymethoxyphenyl) -2-(4sulfophenyl)-2H-tetrazolium) enzymatic assay. Briefly, cells were incubated in the presence of $0.5 \mathrm{mg} . \mathrm{mL}^{-1} \mathrm{MTS}$ for $4 \mathrm{~h}$ to determine mitochondrial enzyme activity. Absorbance was read at $492 \mathrm{~nm}$ with a spectrophotometer Thermoscientific Multiskan FC

Daylight study. For experiments of daylight toxicity, MCF-7 cancer cells were seeded in a 96 multi-well plate and incubated with or without $\mathbf{2}-\mathbf{G}_{2}$ (20 $\mu \mathrm{g} . \mathrm{mL}^{-1}$ ) for 5 hours. $\mathbf{2}-\mathrm{G}_{2}$ was previously solubilized in THF at 5 $\mathrm{mg} / \mathrm{mL}$ and sonicated. After incubation, cells were washed, maintained in fresh culture medium and then submitted or not to daylight for 4 hours The percentage of living cells was determined by MTT (3-(4,5 dimethylthizol-2-yl)-2,5-diphenyltetrazolium bromide) enzymatic assay Briefly, cells were incubated in the presence of $0.5 \mathrm{mg} . \mathrm{mL}^{-1} \mathrm{MTT}$ for 4 hours to determine mitochondrial enzyme activity. Then medium was removed and purple precipitate was dissolved in $150 \mu \mathrm{l}$ ethanol/DMSO (1:1) solution and stirred $30 \mathrm{~min}$. Then absorbance was read at $540 \mathrm{~nm}$.

\section{Acknowledgements}

We acknowledge financial support from CNRS and Région Bretagne for a fellowship to AS (ARED, Biphobio grant). We wish to thank Vincent Hugues for his contribution to two-photon excited fluorescence experiments. We thank MRI (Montpellier RIO Imaging platform) for confocal facilities.

Keywords: dendrimers $\bullet$ photophysics $\bullet$ fluorescence $\bullet$ imaging - photodynamic therapy

[1] a) T. J. Dougherty, J. Clin. Laser Med. Surg. 2002, 20, 3-7; b) J. P. Celli, B. Q. Spring, I. Rizvi, C. L. Evans, K. S. Samkoe, S. Verma, B. W. Pogue, T. Hasan, Chem. Rev. 2010, 110, 2795-2838.

[2] a) N. L. Oleinick, R. L. Morris, I. Belichenko, Photochem. Photobiol. Sci. 2002, 1, 1-21; b) J. F. Lovell, T. W. B. Liu, J. Chen, G. Zheng, Chem. 
Rev. 2010, 110, 2839-2857; c) S. Mallidi, S. Anbil, A.-L. Bulin, G. Obaid, M. Ichikawa, T. Hasan, Theranostics 2016, 6, 2458-2487.

[3] a) F. Bolze, S. Jenni, A. Sour, V. Heitz, Chem. Commun, 2017, 53, 12857-12877; b) Z. Sun, L.-P. Zhang, F. Wu, Y. Zhao, Adv. Funct Mater. 2017, 27, 1704079.

[4] a) J. D. Bhawalkar, N. D. Kumar, C. F. Zhao, P. N. Prasad, Lasers Surg Med. 1997, 15, 201-204; b) W. G. Fisher, W. P. Partridge, C. Dees, E. A. Wachter, Photochem. Photobiol. 1997, 66, 141-155; c) J. R. Starkey, A. K. Rebane, M. A. Drobizhev, F. Meng, A. Gong, A. Elliott, K. McInnerney, C. W. Spangler, Clin. Cancer Res. 2008, 14, 6564-6573 d) H. A. Collins, M. Khurana, E. H. Moriyama, A. Mariampillai, E. Dahlstedt, M. Balaz, M. K. Kuimova, M. Drobizhev, X. D. YangVictor, D. Phillips, A. Rebane, B. C. Wilson, H. L. Anderson, Nat. Photon. 2008, 2 420-424; e) M. Gary-Bobo, Y. Mir, C. Rouxel, D. Brevet, I. Basile, M. Maynadier, O. Vaillant, O. Mongin, M. Blanchard-Desce, A. Morère, M Garcia, J.-O. Durand, L. Raehm, Angew. Chem. Int. Ed. 2011, 50, 11425-11429; f) O. Vaillant, E. Cheikh Khaled, D. Warther, D. Brevet, M. Maynadier, E. Bouffard, F. Salgues, A. Jeanjean, P. Puche, C. Mazerolles, P. Maillard, O. Mongin, M. Blanchard-Desce, L. Raehm, X. Rébillard, J.-O. Durand, M. Gary-Bobo, A. Morère, M. Garcia, Angew. Chem. Int. Ed. 2015, 54, 5952-5956; g) Q. Zou, H. Zhao, Y. Zhao, Y Fang, D. Chen, J. Ren, X. Wang, Y. Wang, Y. Gu, F. Wu, J. Med. Chem. 2015, 58, 7949-7958; h) Y. Huang, F. Qiu, L. Shen, D. Chen, Y. Su, C. Yang, B. Li, D. Yan, X. Zhu, ACS Nano 2016, 10, 10489-10499 i) J. Schmitt, V. Heitz, A. Sour, F. Bolze, P. Kessler, L. Flamigni, B. Ventura, S. Bonnet Célia, É. Tóth, Chem. Eur. J. 2016, 22, 2775-2786; j) J. R. Starkey, E. M. Pascucci, M. A. Drobizhev, A. Elliott, A. K. Rebane, Biochim. Biophys. Acta, Gen. Subj. 2013, 1830, 4594-4603.

[5] N. S. Makarov, M. Drobizhev, A. Rebane, Opt. Express 2008, 16, 4029 4047.

[6] M. Khurana, H. A. Collins, A. Karotki, H. L. Anderson, D. T. Cramb, B. C. Wilson, Photochem. Photobiol. 2007, 83, 1441.

[7] a) H. Rath, J. Sankar, V. PrabhuRaja, T. K. Chandrashekar, A. Nag, D. Goswami, J. Am. Chem. Soc. 2005, 127, 11608; b) R. Misra, R. Kumar, T. K. Chandrashekar, A. Nag, D. Goswami, Org. Lett. 2006, 8, 629-631.

[8] a) K. Ogawa, A. Ohashi, Y. Kobuke, K. Kamada, K. Ohta, J. Am. Chem. Soc. 2003, 125, 13356-13357; b) M. Drobizhev, Y. Stepanenko, Y Dzenis, A. Karotki, A. Rebane, P. N. Taylor, H. L. Anderson, J. Am Chem. Soc. 2004, 126, 15352-15353; c) S. Achelle, P. Couleaud, P. Baldeck, M.-P. Teulade-Fichou, P. Maillard, Eur. J. Org. Chem. 2011 2011, 1271-1279; d) F. Hammerer, S. Achelle, P. Baldeck, P. Maillard, M.-P. Teulade-Fichou, J. Phys. Chem. A 2011, 115, 6503-6508.

[9] a) D. Y. Kim, T. K. Ahn, J. H. Kwon, D. Kim, T. Ikeue, N. Aratani, A. Osuka, M. Shigeiwa, S. Maeda, J. Phys. Chem. A 2005, 109, 29962999; b) T. K. Ahn, K. S. Kim, D. Y. Kim, S. B. Noh, N. Aratani, C. Ikeda A. Osuka, D. Kim, J. Am. Chem. Soc. 2006, 128, 1700-1704; c) M. Pawlicki, M. Morisue, N. K. S. Davis, D. G. McLean, J. E. Haley, E. Beuerman, M. Drobizhev, A. Rebane, A. L. Thompson, S. I. Pascu, G. Accorsi, N. Armaroli, H. L. Anderson, Chem. Sci. 2012, 3, 1541-1547.

[10] a) K. Ogawa, H. Hasegawa, Y. Inaba, Y. Kobuke, H. Inouye, Y. Kanemitsu, E. Kohno, T. Hirano, S.-i. Ogura, I. Okura, J. Med. Chem. 2006, 49, 2276-2283; b) M. Drobizhev, Y. Stepanenko, A. Rebane, C. J. Wilson, T. E. O. Screen, H. L. Anderson, J. Am. Chem. Soc. 2006, 128 $12432-12433$; c) A. Mikhaylov, D. V. Kondratuk, A. Cnossen, H. L. Anderson, M. Drobizhev, A. Rebane, J. Phys. Chem. C 2016, 120, 11663-11670.

[11] a) T. V. Esipova, S. A. Vinogradov, J. Org. Chem. 2014, 79, 8812-8825; b) T. V. Esipova, H. J. Rivera-Jacquez, B. Weber, A. E. Masunov, S. A Vinogradov, J. Am. Chem. Soc. 2016, 138, 15648-15662.

[12] a) W. R. Dichtel, J. M. Serin, C. Edder, J. M. J. Fréchet, M. Matuszewski, L.-S. Tan, T. Y. Ohulchanskyy, P. N. Prasad, J. Am. Chem. Soc. 2004, 126, 5380-5381; b) M. A. Oar, J. M. Serin, W. R Dichtel, J. M. J. Fréchet, T. Y. Ohulchanskyy, P. N. Prasad, Chem. Mater. 2005, 17, 2267-2275; c) R. P. Brinas, T. Troxler, R. M. Hochstrasser, S. A. Vinogradov, J. Am. Chem. Soc. 2005, 127, 11851-
11862; d) D.-I. Lee, T. Goodson, J. Phys. Chem. B 2006, 110, 25582 25585; e) J.-B. Verlhac, G. Clermont, M. Blanchard-Desce, J. Porphyrins Phthalocyanines 2017, 21, 77-87.

[13] a) O. Mongin, V. Hugues, M. Blanchard-Desce, A. Merhi, S. Drouet, D. Yao, C. Paul-Roth, Chem. Phys. Lett. 2015, 625, 151-156; b) D. Yao, V. Hugues, M. Blanchard-Desce, O. Mongin, C. O. Paul-Roth, F. Paul, New J. Chem. 2015, 39, 7730-7733; c) D. Yao, X. Zhang, A. Triadon, N. Richy, O. Mongin, M. Blanchard-Desce, F. Paul, O. Paul-Roth Christine, Chem. Eur. J. 2016, 23, 2635-2647; d) D. Yao, X. Zhang, S. Abid, L. Shi, M. Blanchard-Desce, O. Mongin, F. Paul, C. O. Paul-Roth, New J. Chem. 2018, 42, 395-401.

[14] O. Mongin, M. Sankar, M. Charlot, Y. Mir, M. Blanchard-Desce, Tetrahedron Letters 2013, 54, 6474-6478.

[15] a) S. Kim, T. Y. Ohulchanskyy, H. E. Pudavar, R. K. Pandey, P. N. Prasad, J. Am. Chem. Soc. 2007, 129, 2669-2675; b) S.-H. Cheng, C.C. Hsieh, N.-T. Chen, C.-H. Chu, C.-M. Huang, P.-T. Chou, F.-G. Tseng, C.-S. Yang, C.-Y. Mou, L.-W. Lo, Nano Today 2011, 6, 552-563; c) J. G. Croissant, S. Picard, D. Aggad, M. Klausen, C. Mauriello Jimenez, M. Maynadier, O. Mongin, G. Clermont, E. Genin, X. Cattoën M. Wong Chi Man, L. Raehm, M. Garcia, M. Gary-Bobo, M. BlanchardDesce, J.-O. Durand, J. Mater. Chem. B 2016, 4, 5567-5574.

[16] Z.-D. Qi, D.-W. Li, P. Jiang, F.-L. Jiang, Y.-S. Li, Y. Liu, W.-K. Wong, K.-W. Cheah, J. Mater. Chem. 2011, 21, 2455-2458.

[17] S. Dayal, C. Burda, J. Am. Chem. Soc. 2008, 130, 2890-2891.

[18] X. Shen, L. Li, H. Wu, S. Q. Yao, Q.-H. Xu, Nanoscale 2011, 3, 5140 5146

[19] a) M. Velusamy, J.-Y. Shen, J. T. Lin, Y.-C. Lin, C.-C. Hsieh, C.-H. Lai, C.-W. Lai, M.-L. Ho, Y.-C. Chen, P.-T. Chou, J.-K. Hsiao, Adv. Funct. Mater. 2009, 19, 2388-2397; b) S. C. Boca, M. Four, A. Bonne, B. van der Sanden, S. Astilean, P. L. Baldeck, G. Lemercier, Chem. Commun, 2009, 0, 4590-4592; c) E. M. Boreham, L. Jones, A. N. Swinburne, M Blanchard-Desce, V. Hugues, C. Terryn, F. Miomandre, G. Lemercier L. S. Natrajan, Dalton Trans. 2015, 44, 16127-16135.

[20] a) P. K. Frederiksen, M. Jørgensen, P. R. Ogilby, J. Am. Chem. Soc 2001, 123, 1215-1221; b) S. P. Mcllroy, E. Cló, L. Nikolajsen, P. K Frederiksen, C. B. Nielsen, K. V. Mikkelsen, K. V. Gothelf, P. R. Ogilby J. Org. Chem. 2005, 70, 1134-1146; c) C. B. Nielsen, M. Johnsen, J. Arnbjerg, M. Pittelkow, S. P. Mcllroy, P. R. Ogilby, M. Jorgensen, J. Org Chem. 2005, 70, 7065-7079; d) T. Gallavardin, C. Armagnat, O. Maury, P. L. Baldeck, M. Lindgren, C. Monnereau, C. Andraud, Chem. Commun, 2012, 48, 1689-1691; e) C. Tang, P. Hu, E. Ma, M. Huang, Q. Zheng, Dyes Pigm. 2015, 117, 7-15.

[21] C. Rouxel, M. Charlot, Y. Mir, C. Frochot, O. Mongin, M. BlanchardDesce, New J. Chem. 2011, 35, 1771-1780.

[22] a) J.-P. Majoral, A.-M. Caminade, Chem. Rev. 1999, 99, 845-880; b) A.-M. Caminade, A. Hameau, J.-P. Majoral, Dalton Trans. 2016, 45, 1810-1822.

[23] a) A.-M. Caminade, C.-O. Turrin, J.-P. Majoral, New J. Chem. 2010, 34, 1512-1524; b) M. Maszewska, J. Leclaire, M. Cieslak, B. Nawrot, A Okruszek, A.-M. Caminade, J.-P. Majoral, Oligonucleotides 2003, 13, 193-205; c) J. Solassol, C. Crozet, V. Perrier, J. Leclaire, F. Beranger, A.-M. Caminade, B. Meunier, D. Dormont, J.-P. Majoral, S. Lehmann, J. Gen. Virol. 2004, 85, 1791-1799; d) C.-O. Turrin, J.-P. Majoral Phosphorous Dendrimers in Biology and Nanomedicine: Syntheses, Characterization, and Properties, Pan Stanford Publishing: Singapore, 2018

[24] a) O. Mongin, T. R. Krishna, M. H. V. Werts, A.-M. Caminade, J.-P Majoral, M. Blanchard-Desce, Chem. Commun, 2006, 915-917; b) O. Mongin, C. Rouxel, J.-M. Vabre, Y. Mir, A. Pla-Quintana, Y. Wei, A.-M. Caminade, J. P. Majoral, M. Blanchard-Desce, Proc. SPIE 2009, 7403 740303.

[25] a) T. R. Krishna, M. Parent, M. H. V. Werts, L. Moreaux, S. Gmouh, S. Charpak, A.-M. Caminade, J.-P. Majoral, M. Blanchard-Desce, Angew. Chem. Int. Ed. 2006, 45, 4645-4648; b) O. Mongin, C. Rouxel, A.-C. Robin, A. Pla-Quintana, T. Rama Krishna, G. Recher, F. Tiaho, A.-M. 
Caminade, J.-P. Majoral, M. Blanchard-Desce, Proc. SPIE 2008, 7040 704006

[26] L. Porrès, B. K. G. Bhatthula, M. Blanchard-Desce, Synthesis 2003, 1541-1544.

[27] L.-H. Wu, C.-S. Chu, N. Janarthanan, C.-S. Hsu, J. Polym. Res. 2000 7, 125-134.

[28] F. Li, Z. Chen, W. Wei, H. Cao, Q. Gong, F. Teng, L. Qian, Y. Wang, J. Phys. D: Appl. Phys. 2004, 37, 1613-1616.

[29] a) A.-M. Caminade, J.-P. Majoral, Acc. Chem. Res. 2004, 37, 341-348; b) A.-M. Caminade, J.-P. Majoral, Prog. Polym. Sci. 2005, 30, 491-505.

[30] N. Launay, A.-M. Caminade, J. P. Majoral, J. Organomet. Chem. 1997, 529, 51-58.

[31] C. Katan, S. Tretiak, M. H. V. Werts, A. J. Bain, R. J. Marsh, N. Leonczek, N. Nicolaou, E. Badaeva, O. Mongin, M. Blanchard-Desce, J Phys. Chem. B 2007, 111, 9468-9483.

[32] O. Mongin, A. Pla-Quintana, F. Terenziani, D. Drouin, C. Le Droumaguet, A.-M. Caminade, J.-P. Majoral, M. Blanchard-Desce, New J. Chem. 2007, 31, 1354-1367.

[33] a) A.-C. Robin, V. Parthasarathy, A. Pla-Quintana, O. Mongin, F. Terenziani, A.-M. Caminade, J.-P. Majoral, M. Blanchard-Desce, Proc.
SPIE 2010, 7774, 77740N; b) C. Rouxel, O. Mongin, A. Hameau, A Ouali, M. Blanchard-Desce, J.-P. Majoral, A.-M. Caminade, Can. J. Chem. 2017, 95, 948-953.

[34] a) M. Drobizhev, A. Rebane, Z. Suo, C. W. Spangler, J. Lumin. 2005 111, 291-305; b) O. Varnavski, X. Yan, O. Mongin, M. Blanchard-Desce, T. Goodson, III, J. Phys. Chem. C 2007, 111, 149-162.

[35] F. Terenziani, A. Painelli, C. Katan, M. Charlot, M. Blanchard-Desce, J. Am. Chem. Soc. 2006, 128, 15742-15755

[36] S. Govindarajan, P. B. Nagabalasubramanian, Int. J. Adv. Sci. Eng 2015, 2, 75-86.

[37] a) M. Drobizhev, S. Tillo, N. S. Makarov, T. E. Hughes, A. Rebane, J. Phys. Chem. B 2009, 113, 855-859; b) M. Drobizhev, S. Tillo, N. S Makarov, T. E. Hughes, A. Rebane, J. Phys. Chem. B. 2009, 113, $12860-12864$.

[38] a) G. A. Crosby, J. N. Demas, J. Phys. Chem. 1971, 75, 991-1024; b) D F. Eaton, Pure Appl. Chem. 1988, 60,1107-1114.

[39] C. Xu, W. W. Webb, J. Opt. Soc. Am. B 1996, 13, 481.

[40] M. H. V. Werts, N. Nerambourg, D. Pélégry, Y. Le Grand, M. Blanchard-Desce, Photochem. Photobiol. Sci. 2005, 4, 531-538. 


\section{Entry for the Table of Contents}

Layout 2:

\section{FULL PAPER}
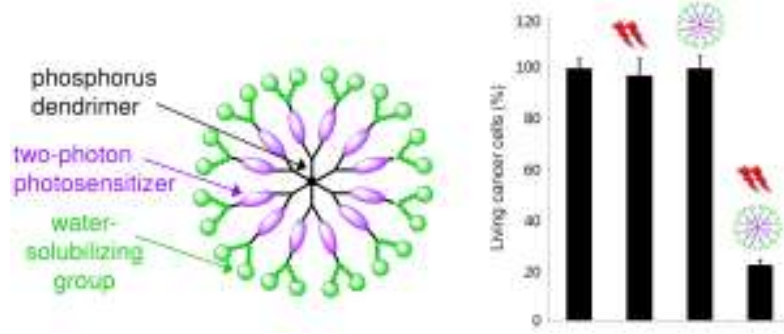

New dendrimers combining large two-photon brightness and photosensitizing properties are efficient cell death inducers under two-photon irradiation in the NIR, while being non toxic in the dark and under daylight exposition.
A. Sourdon, M. Gary-Bobo, M.

Maynadier, M. Garcia, J.-P. Majoral, A.-

M. Caminade, O. Mongin, * $M$.

Blanchard-Desce*

Page No. - Page No.

Dendrimeric nanoparticles for twophoton photodynamic therapy and imaging: synthesis, photophysical properties, innocuousness in daylight and cytotoxicity under two-photon irradiation in the NIR 